\title{
Ecological impacts of non-native Pacific oysters (Crassostrea gigas) and management measures for protected areas in Europe
}

\author{
Roger J. H. Herbert ${ }^{1}$ • John Humphreys ${ }^{1}$ - Clare. J. Davies ${ }^{1}$ • \\ Caroline Roberts $^{2} \cdot$ Steve Fletcher $^{3,4}$ - Tasman. P. Crowe ${ }^{5}$
}

Received: 3 April 2016/Revised: 10 August 2016/Accepted: 27 August 2016/

Published online: 1 October 2016

(C) The Author(s) 2016. This article is published with open access at Springerlink.com

\begin{abstract}
Pacific oysters are now one of the most 'globalised' marine invertebrates. They dominate bivalve aquaculture production in many regions and wild populations are increasingly becoming established, with potential to displace native species and modify habitats and ecosystems. While some fishing communities may benefit from wild populations, there is now a tension between the continued production of Pacific oysters and risk to biodiversity, which is of particular concern within protected sites. The issue of the Pacific oyster therefore locates at the intersection between two policy areas: one concerning the conservation of protected habitats, the other relating to livelihoods and the socio-economics of coastal aquaculture and fishing communities. To help provide an informed basis for management decisions, we first summarise evidence for ecological impacts of wild Pacific oysters in representative coastal habitats. At local scales, it is clear that establishment of Pacific oysters can significantly alter diversity, community structure
\end{abstract}

Communicated by David Hawksworth.

This article belongs to the Topical Collection: Coastal and marine biodiversity.

Electronic supplementary material The online version of this article (doi:10.1007/s10531-016-1209-4) contains supplementary material, which is available to authorized users.

Roger J. H. Herbert

rherbert@bournemouth.ac.uk

1 Faculty of Science and Technology, Department of Life and Environmental Sciences, Bournemouth University, Talbot Campus, Fern Barrow, Poole, Dorset BH12 5BB, UK

2 ABP Marine Environmental Research Ltd., Quayside Suite, Medina Chambers, Town Quay, Southampton, Hampshire SO14 2AQ, UK

3 Centre for Marine and Coastal Policy Research, Plymouth University, Plymouth PL4 8AA, UK

4 United Nations Environment Programme-World Conservation Monitoring Centre, Huntingdon Road, Cambridge CB3 0DL, UK

5 Earth Institute and School of Biology and Environmental Science, Science West, University College Dublin, Belfield, Dublin 4, Ireland 
and ecosystem processes, with effects varying among habitats and locations and with the density of oysters. Less evidence is available to evaluate regional-scale impacts. A range of management measures have been applied to mitigate negative impacts of wild Pacific oysters and we develop recommendations which are consistent with the scientific evidence and believe compatible with multiple interests. We conclude that all stakeholders must engage in regional decision making to help minimise negative environmental impacts, and promote sustainable industry development.

Keywords Invasive species - Non-indigenous species - Environmental risk assessment · Aquaculture $\cdot$ Fisheries $\cdot$ Marine protected areas

\section{Introduction}

The proliferation of non-native species around the globe is considered one of the most important biosecurity concerns of our modern age (IUCN 2000). Although to date, and to the best of knowledge no marine taxon has become extinct as a result of the introduction of non-native species (Rilov 2009) many native species decline when they interact directly or indirectly with non-native species-some have declined considerably and there have been local (site specific) species extinctions as a result of competition (Byers 2009). Invasive species that have the greatest impact are often 'ecosystem engineers' that affect organisms via changes to the physical and chemical environment (Jones et al. 1994, 1997; Jones and Gutierrez 2007; Crooks 2009). These species may create, destroy or modify habitats (Crooks 2009; Sousa et al. 2009; Padilla 2010; Markert et al. 2010; Van der Zee et al. 2012).

Pacific oysters (Crassostrea gigas) are now one of the most 'globalised' marine invertebrates and dominate bivalve production in many regions (Ruesink et al. 2005; FAO $2016 \mathrm{a}, \mathrm{b})$. The oysters have been introduced to 66 countries outside their native range, mainly for aquaculture, and there are now established self-sustaining populations in at least 17 countries (Ruesink et al. 2005; Smaal et al. 2006; Cardoso et al. 2007; Wrange et al. 2010). Although of considerable importance for coastal economies around the world, the introduction of $C$. gigas has also been very significant in maintaining the oyster fishing and cultivation culture and traditions of communities that have previously relied on native oysters, which in many regions are now declining (Goulletquer and Heral 1997; Zu Ermgassen et al. 2012; Humphreys et al. 2014).

Crassostrea gigas is native in the NW Pacific and Sea of Japan and occurs primarily in warm temperate regions between latitudes $30^{\circ} \mathrm{N}-48^{\circ} \mathrm{N}$. It is an estuarine species, generally attached to firm bottom substrates, rocks, debris and shells from the lower intertidal zone to depths of $40 \mathrm{~m}$ (FAO 2016a). In Europe and elsewhere, there has been confusion with the introduction of the Portuguese oyster C. angulata (Humphreys et al. 2014). Although they are currently considered separate species they may yet be shown to be conspecifics (Gofas 2013).

Pacific oysters have a pelagic larval duration of 2-4 weeks, depending on temperature and nutrition (Rico-Villa et al. 2006; Syvret et al. 2008). The final larval stage will settle on the shore or seabed and develop a hard shell that in time will be recognisable as a juvenile oyster (Arakawa 1990; Reise 1998; Troost 2010). In this review, 'wild settlement' refers to the point when the oysters are first observed on the shore or subtidally either as juvenile or adult stages. Oysters become 'established' when reproduction is at a level sufficient to 
ensure continued survival. It is likely that a combination of factors enable wild establishment, including a lack of natural predators within receiving systems, beneficial traits such as rapid growth and rising air and sea temperatures as a result of global warming (see Troost 2010 for review). High temperatures appear to have caused an increased spawning frequency in parts of coastal Europe and wild settlement has occurred along much of the continental shoreline (Drinkwaard 1999; Reise et al. 2005; Troost 2010; Wrange et al. 2010; Lejart and Hily 2005, 2011; Herbert et al. 2012; Dolmer 2014). Oyster larvae are known to settle gregariously and to be attracted to conspecifics (Arakawa 1990; Tamburri and Zimmer 2007). Having initially settled on a shell or a small stone, clumps of oysters may merge to form dense aggregations and potentially a reef. A reef is formed when oyster densities are so high that little space may exist for subsequent oyster settlements or other species on the substrate surface. However, most Pacific oyster reefs in the Dutch and German Wadden Sea do not cover $100 \%$ of the substrate and contain bare patches where soft-sediment communities are still present and shrimps and small fish may be found in shallow pools (Troost 2010).

Reefs have generally been described in terms of the density of oysters per square metre, as opposed to the percentage coverage on the substratum surface. However where densities of live, mature oysters approach or exceed $\sim 200$ ind. $\mathrm{m}^{-2}$ there is generally little underlying natural substratum visible, especially as an amount of empty shell is also always present (personal observation). In some regions, significant areas of intertidal Pacific oyster 'reef' have developed with densities of 700 ind. $\mathrm{m}^{-2}$ (Wehrmann et al. 2006 cited in Markert et al. 2010) creating a hard substratum upon other habitats. Where the oysters have colonised mussel beds (Mytilus edulis) in the Wadden Sea, the density of live and dead oysters can be 2000 ind. $\mathrm{m}^{-2}$ (Markert et al. 2013). Subsequent settlements will often be on existing oysters, and over time a hard concretion of live and dead oysters develops (Walles et al. 2015), although the area, height and thickness of the reef often vary throughout a site. In the Oosterschelde estuary (Netherlands) wild settlement was first observed in 1975 and the first reefs were mapped in 1980 (Drinkwaard 1999; Smaal et al. 2009). However, in south-east England, although spawning had been observed intermittently over several decades during favourable summers (Spencer et al. 1994; Herbert et al. 2012), dense wild settlement and reefs first became noticed in the mid 2000s (Herbert et al. 2012).

\section{Conservation and management concerns}

With naturalization of non-native aquaculture species, there is a dilemma between encouraging the beneficial services provided by extensive fisheries and aquaculture and the potential damage caused by their proliferation and potentially invasive traits (Goulletquer 2009; Humphreys 2010; Herbert et al. 2012; Humphreys et al. 2014). Although wild settlement can be beneficial for coastal fishing communities, in protected areas there is now a tension between the continued production of the Pacific oyster and risk to biodiversity associated with the growth of wild populations (Goulletquer 2009; Herbert et al. 2012; Humphreys et al. 2014). Many coastal species and habitats have been designated as protected areas under national and international conservation agreements e.g. European Habitats Directive (92/43/EEC) and Ramsar Sites. Conservation agencies and regulators are concerned that habitats and species of conservation interest are at risk from competition, displacement and proximity to non-indigenous species. If following assessment, sites protected under European law are deemed to be in poor (unfavourable) condition then the European Commission can initiate formal infringement proceedings that can result in 
financial sanctions for Member States if non-compliance is unresolved (European Commission 2016a).

In parts of continental Europe and in temperate regions elsewhere, the proliferation of wild $C$. gigas is now regarded as an 'invasion' as $C$. gigas is spreading rapidly and is displacing native species and habitats (Diederich et al. 2005; Ruesink et al. 2005; Smaal et al. 2005; Cognie et al. 2006; Lejart and Hily 2005). Moreover the species is listed as 'one of the worst 100 alien species in Europe' (DAISIE 2016). There are also negative socio-economic impacts of wild settlement that range from potential injury to the public from 'razor sharp oyster shells', the maintenance of navigational channels for recreational craft, aesthetic issues (personal communications to authors) and trophic competition with commercial mussel farming (Wijsman et al. 2008). In the southwest Atlantic coast of France, wild populations of $C$. gigas were destroyed because they were competing with cultivated Pacific oysters and therefore limiting growth (Goulletquer 2009).

The overall economic importance of $C$. gigas in many of these regions is extremely high (FAO 2016a, b). However in the UK and parts of Ireland, where the industry is yet to realise its full potential, the future of Pacific oyster aquaculture within designated protected sites is at risk due to conservation concerns about the potential impact of wild oysters (Herbert et al. 2012; Humphreys et al. 2014). The issue of the Pacific oyster therefore locates at the intersection between two policy areas: one concerning the conservation of protected habitats, the other relating to livelihoods and the socio-economics of coastal aquaculture and fishing communities. Other affected stakeholders include port authorities and recreational bodies.

We aim to find sustainable solutions for the aquaculture industry, fisheries, conservation agencies and regulators. Our first objective is to review the evidence for negative impacts of wild Pacific oysters on selected, yet representative, broad-scale coastal habitats and species. Our second objective is to assess the risks and review potential management measures that have been trialled or suggested as a way of containing the impact of the oysters.

\section{Methods and approach}

This review considers evidence of potential direct impacts of wild settlement and establishment of non-native $C$. gigas on intertidal and subtidal habitats often found within protected areas. The exclusion of some habitats does not necessarily imply that the species will have no impact in them, although deep sea habitats are beyond the species range. We have not specifically considered the impact of $C$. gigas introductions on the spread and ecological and economic damage caused by the 'hitch-hiking' of other non-native species, parasites and pathogens. Neither have we considered in detail the direct environmental impact of cultivation of $C$. gigas.

Although the focus is on European seas, information on ecological impacts was obtained from temperate regions around the world where $C$. gigas is cultivated and where habitats are broadly similar. The published literature was searched using the terms shown in Online Resource Appendix A. Information was obtained from areas with warm or cold temperate climate and within similar 'Biogeographical Realms' (Spalding et al. 2007). This was primarily undertaken through searching online research databases and catalogues (ISI Web of Science, JSTOR, ScienceDirect, Scopus, Google Scholar). To ensure that relevant 'grey literature' was incorporated, an internet search using the same search terms 
was conducted and professional networks and organisations likely to hold grey literature and information on unpublished and on-going studies were contacted via their websites and libraries (e.g. non-governmental conservation organisations, fisheries research institutes). Scientific experts with specific knowledge about the Pacific oyster and its ecology and habitat were contacted by phone and email and experts and stakeholders professionally engaged in aquaculture were consulted by email with a short questionnaire (UK only), by phone, face-to-face interviews or through visits to cultivation and production businesses. Many of these organisations and experts are listed within the Acknowledgements section of this review. The evidence collected in this way was used as the basis for a narrative review addressing the objectives stated above.

\section{Results}

\section{Impacts on species diversity and ecosystem functioning}

Although studies of ecological impact encompass a range of broad-scale intertidal habitats, the number of replicated studies within some habitats and across different regions is relatively low (Table 1). Ecological impacts as a result of reef formation are almost entirely reported from Europe; in the Pacific North-west of the USA, reef formation appears not as extensive. Habitats that are causing most concern are intertidal rocky reefs (Fig. 1), muddy intertidal habitats (Fig. 2) and biogenic reefs, such as those formed by the honeycomb worm Sabellaria alveolata (Fig. 3). Studies on ecological impacts are generally local in scale and there has been little work so far on impacts on subtidal species as the extent of recruitment and colonisation of sublittoral habitats is currently unclear. A study on the micro-tidal coast of Sweden (Hollander et al. 2015) was technically sublittoral, however the species and communities investigated (M. edulis beds and soft-sediments) were comparable with those in the lower intertidal habitats of macro-tidal shores. Studies of impacts on seagrass have only been carried out in the Pacific North-west, whereas impacts on M. edulis beds have to date only been studied in Europe, which may reflect differences in the susceptibility of habitats to succumb to wild settlement in different temperate realms. It is uncertain to what extent $C$. gigas has had an influence on the decline of intertidal mussel beds. It is possible that $C$. gigas has colonized shell debris associated with former mussel beds and interfered with their re-colonisation through occupation of their former habitat, although there is no experimental evidence for this. Variability in mussel survival is likely to be related to regional levels of invertebrate predation (Nehls et al. 2006; K Reise pers.comm). Reduced fitness may also have facilitated the decline of mussels, as experiments have shown that mussels migrate downwards through the oyster reef to avoid crab predation, yet at the expense of reduced food supply and growth (Eschweiler and Christensen 2011). Yet, in some parts of the central Wadden Sea mussels are now increasing in the shelter of $C$. gigas reefs (Nehls et al. 2009; Markert et al. 2010).

Small-scale experimental manipulations $\left(0.25 \mathrm{~m}^{-2}\right.$ plots $)$ using transplanted oysters on mudflats at two different locations in Ireland showed that invertebrate species density and diversity increased between $5 \%$ cover and $50 \%$ cover of $C$. gigas, but then plateaued with no further increase at $100 \%$ cover (Green and Crowe 2014). The responses of many species differed between locations and over time, suggesting that some effects are contextdependent. A study on mussel beds have found increases in macro-invertebrate diversity 
Table 1 Ecological impacts of Pacific oysters in temperate regions

\begin{tabular}{|c|c|c|c|}
\hline Habitat & Region & Impact & References \\
\hline \multirow[t]{8}{*}{ Littoral rock } & Southern England, Kent & $\begin{array}{l}\text { Patches of } C \text {. gigas reef ( } 200 \\
\text { ind. } \mathrm{m}^{-2} \text { ) present on lower } \\
\text { shore of chalk reef (Fig. 1) }\end{array}$ & Herbert et al. (2012) \\
\hline & $\begin{array}{l}\text { France, Bay of Brest } \\
\text { (moderately exposed } \\
\text { shore) }\end{array}$ & $\begin{array}{l}\text { C. gigas reef at all tidal levels } \\
\text { (Mean High Water to Mean } \\
\text { Low Water); Biomass and } \\
\text { species richness significantly } \\
\text { higher on } C \text {. gigas reefs } \\
\text { compared to adjacent rock; } \\
\text { Deposit and detritus feeders } \\
\text { occurred only on oyster reefs } \\
\text { and not on adjacent rock }\end{array}$ & Lejart and Hily (2011) \\
\hline & Ireland & $\begin{array}{l}\text { Experimental addition of living } \\
\text { or dead } C \text {. gigas. Effects } \\
\text { varied with state and cover of } \\
\text { oysters. Boulders with lowest } \\
\text { cover of living } C \text {. gigas } \\
\text { supported greatest diversity }\end{array}$ & Green and Crowe (2013) \\
\hline & USA, Pacific Northwest & $\begin{array}{l}\text { C. gigas common on sheltered } \\
\text { rocky shores (low energy } \\
\text { littoral rock) and rare }(<10 \% \\
\text { cover) on exposed shores }\end{array}$ & Ruesink (2007) \\
\hline & $\begin{array}{l}\text { Canada, Strait of } \\
\text { Georgia }\end{array}$ & $\begin{array}{l}\text { Reef formation not reported } \\
\text { from British Columbia, } \\
\text { though higher densities are } \\
\text { present in areas where } \\
\text { warmer waters cause more } \\
\text { frequent settlement }\end{array}$ & J. Ruesink (Pers. comm) \\
\hline & & $\begin{array}{l}\text { C. gigas settles within the } \\
\text { barnacle zone where they } \\
\text { may provide a greater surface } \\
\text { area for settlement. In } \\
\text { experimental manipulations, } \\
\text { seastars and crabs reduced } \\
\text { monthly survival rates of } C \text {. } \\
\text { gigas by } 25 \% \text { relative to } \\
\text { caged oysters Some } \\
\text { neighbouring species on } \\
\text { exposed rocky sites might } \\
\text { facilitate survival of } C \text {. gigas } \\
\text { by reducing physical stresses }\end{array}$ & $\begin{array}{l}\text { Ruesink (2007); Ruesink et al. } \\
\text { (2005) }\end{array}$ \\
\hline & $\begin{array}{l}\text { Canada, British } \\
\text { Columbia }\end{array}$ & $\begin{array}{l}\text { C. gigas was able to modify the } \\
\text { thermal regime of its habitat } \\
\text { and provide refugia for those } \\
\text { species that might otherwise } \\
\text { suffer from desiccation }\end{array}$ & Padilla (2010) \\
\hline & Argentina (1982) & $\begin{array}{l}\text { Among eight epifaunal species, } \\
\text { three occurred at higher } \\
\text { densities within oyster beds } \\
\text { and three were more } \\
\text { abundant outside these areas }\end{array}$ & Escapa et al. (2004) \\
\hline $\begin{array}{l}\text { Littoral } \\
\text { sediments }\end{array}$ & $\begin{array}{l}\text { Southern England, } \\
\text { North Sea, English } \\
\text { Channel }\end{array}$ & $\begin{array}{l}\text { Reef formation since } 2007 \\
\text { (Fig. 2) }\end{array}$ & Herbert et al. (2012) \\
\hline
\end{tabular}


Table 1 continued

\begin{tabular}{|c|c|c|c|}
\hline Habitat & Region & Impact & References \\
\hline & Wadden Sea & $\begin{array}{l}\text { Reef formation present on } \\
\text { lower shore }\end{array}$ & Reise (1998) \\
\hline & $\begin{array}{l}\text { Netherlands, } \\
\text { Oosterschelde estuary }\end{array}$ & $\begin{array}{l}\text { First natural recruitment in } \\
\text { 1975. Reefs mapped in } 1980\end{array}$ & $\begin{array}{l}\text { Drinkwarrd (1999); Smaal } \\
\text { et al. (2009) }\end{array}$ \\
\hline & $\begin{array}{l}\text { France, Bay of Brest, } \\
\text { Brittany }\end{array}$ & $\begin{array}{l}\text { Invertebrate species richness } \\
\text { on mud beneath } C \text {. gigas reef } \\
\text { was twice that of adjacent } \\
\text { mudflats and dominated by } \\
\text { carnivores, compared to } \\
\text { suspension feeders in } \\
\text { mudflats }\end{array}$ & Lejart and Hily $(2005,2011)$ \\
\hline & Ireland & $\begin{array}{l}\text { Experimental addition of } \\
\text { different covers of oysters in } \\
\text { small plots in two estuaries. } \\
\text { Diversity and abundance of } \\
\text { species increased with cover } \\
\text { of oysters. Effects on } \\
\text { microbial communities and } \\
\text { ecosystem processes varied } \\
\text { with cover. Sediment-water } \\
\text { fluxes and turnover of } \\
\text { ammonium and silicate were } \\
\text { greatest at medium cover and } \\
\text { decreased with greatest cover }\end{array}$ & $\begin{array}{l}\text { Green and Crowe (2014); } \\
\text { Green et al. }(2012,2013)\end{array}$ \\
\hline \multirow[t]{2}{*}{$\begin{array}{l}\text { Saltmarshes } \\
\text { and saline } \\
\text { reed beds }\end{array}$} & Southern England, Kent & $\begin{array}{l}\text { No settlement observed, } \\
\text { however stabilization of } \\
\text { sediment by oyster shells } \\
\text { may both facilitate further } \\
\text { colonisation of non-native } \\
\text { Spartina anglica and } \\
\text { potentially create a firm } \\
\text { habitat for oyster settlement }\end{array}$ & McKnight (2011) \\
\hline & Argentina & $\begin{array}{l}\text { Colonisation of } C \text {. gigas on the } \\
\text { stems of the saltmarsh cord } \\
\text { grass Spartina alterniflora }\end{array}$ & Escapa et al. (2004) \\
\hline $\begin{array}{l}\text { Saline } \\
\text { lagoons }\end{array}$ & $\begin{array}{l}\text { Southern England, Fleet } \\
\text { Lagoon (1988) }\end{array}$ & $\begin{array}{l}\text { Little settlement. The special } \\
\text { flushing characteristics of the } \\
\text { lagoon and crab predation } \\
\text { may provide resilience to } \\
\text { wild settlement }\end{array}$ & Eno (1994) \\
\hline & France & $\begin{array}{l}\text { C. gigas is cultivated in micro- } \\
\text { tidal lagoons and has } \\
\text { established wild populations } \\
\text { in some areas }\end{array}$ & Miossec et al. (2009) \\
\hline $\begin{array}{l}\text { Blue mussel } \\
\text { beds } \\
\text { (Mytilus } \\
\text { edulis) }\end{array}$ & $\begin{array}{l}\text { Netherlands, Wadden } \\
\text { Sea From Mean Tide } \\
\text { Level (MTL) to the } \\
\text { shallow subtidal }\end{array}$ & $\begin{array}{l}\text { Mytilus-beds have changed to } \\
\text { mixed reefs dominated by } \\
95 \% \text { C. gigas. Mussels } \\
\text { recruit frequently and settle } \\
\text { amongst the oysters, } \\
\text { migrating to lower regions in } \\
\text { the interspaces between the } \\
\text { oysters to evade predation }\end{array}$ & $\begin{array}{l}\text { Nehls and Buttger (2007); } \\
\text { Nehring et al. (2009); Fey } \\
\text { et al. (2010); Eschweiler and } \\
\text { Christensen (2011) }\end{array}$ \\
\hline
\end{tabular}


Table 1 continued

\begin{tabular}{|c|c|c|c|}
\hline Habitat & Region & Impact & References \\
\hline & Germany, Wadden Sea & $\begin{array}{l}\text { Mixed mussel-oyster reef } \\
\text { showed increased species } \\
\text { richness, abundance, } \\
\text { biomass, diversity and } \\
\text { deposit feeding species, } \\
\text { compared to mussel beds }\end{array}$ & Markert et al. (2010) \\
\hline & $\begin{array}{l}\text { Sweden, Skagerrak, } \\
\text { shallow subtidal }\end{array}$ & $\begin{array}{l}\text { No significant differences in } \\
\text { macrofaunal species richness } \\
\text { compared to oyster beds, } \\
\text { however species abundance } \\
\text { in oyster beds was } \\
\text { statistically higher in two out } \\
\text { of three sites. Differences in } \\
\text { macrofaunal composition } \\
\text { were inconsistent }\end{array}$ & Hollander et al. (2015) \\
\hline & Ireland & $\begin{array}{l}\text { Experimental addition of } \\
\text { different covers of oysters in } \\
\text { small plots in two estuaries. } \\
\text { No effects on diversity or } \\
\text { abundance of associated } \\
\text { fauna, except a decrease on } \\
\text { one sampling occasion at one } \\
\text { site. Ecosystem processes } \\
\text { including respiration, } \\
\text { sediment-water fluxes and } \\
\text { turnover of ammonium and } \\
\text { silicate increased with } \\
\text { increasing cover of oysters }\end{array}$ & $\begin{array}{l}\text { Green and Crowe (2013); } \\
\text { Green et al. (2012) }\end{array}$ \\
\hline \multirow{4}{*}{$\begin{array}{l}\text { Polychaete } \\
\text { worm reefs } \\
\text { (Sabellaria } \\
\text { alveolata) }\end{array}$} & $\begin{array}{l}\text { France, Bay of Mont- } \\
\text { Saint Michel }\end{array}$ & $\begin{array}{l}\text { Oysters are colonising some } S \text {. } \\
\text { alveolata reefs with } \\
\text { densities }>100 \text { ind. } \mathrm{m}^{-2}\end{array}$ & Dubois et al. (2006) \\
\hline & $\begin{array}{l}\text { France, Bay of Mont- } \\
\text { Saint Michel }\end{array}$ & $\begin{array}{l}\text { Higher species richness } \\
\text { recorded on Sabellaria reefs } \\
\text { colonised with oysters (and } \\
\text { with oysters and algae). } \\
\text { Colonisation has led to } \\
\text { damage of Sabellaria by } \\
\text { recreational oyster } \\
\text { harvesters. aquaculture is } \\
\text { also thought to have } \\
\text { contributed to habitat } \\
\text { deterioration }\end{array}$ & Desroy et al. (2011); (Fig. 3) \\
\hline & $\begin{array}{l}\text { France, Bourgneuf Bay, } \\
\text { Brittany }\end{array}$ & $\begin{array}{l}\text { Growth and settlement of wild } \\
\text { C. gigas has transformed } \\
\text { areas where former } S \text {. } \\
\text { alveolata beds had } \\
\text { previously been recorded, so } \\
\text { recolonization is now } \\
\text { unlikely }\end{array}$ & Cognie et al. (2006) \\
\hline & Ireland & $\begin{array}{l}\text { Oysters attached } \\
\text { experimentally to topsides of } \\
\text { boulders inhibited settlement } \\
\text { of S.alveolata on undersides }\end{array}$ & Green and Crowe (2013) \\
\hline
\end{tabular}


Table 1 continued

\begin{tabular}{|c|c|c|c|}
\hline Habitat & Region & Impact & References \\
\hline $\begin{array}{l}\text { Sabellaria } \\
\text { spinulosa }\end{array}$ & $\begin{array}{l}\text { Southern England, Kent } \\
\text { extreme lower shore }\end{array}$ & $\begin{array}{l}\text { An area of intertidal } S \text {. } \\
\text { spinulosa in reef formation is } \\
\text { being overgrown by } C \text {. gigas }\end{array}$ & McKnight $(2011,2012)$ \\
\hline $\begin{array}{l}\text { Lanice } \\
\quad \text { conchilega }\end{array}$ & $\begin{array}{l}\text { Southern England, Kent } \\
\text { Extreme lower shore }\end{array}$ & $\begin{array}{l}\text { Chalk reef colonised by } 50 \% \\
\text { cover of L.conchilega worm } \\
\text { reef is partially displaced by } \\
\text { Pacific oysters (maximum } \\
\text { density of C. gigas } 14 \text { ind. } \\
\mathrm{m}^{-2} \text { ) }\end{array}$ & McKnight (2011) \\
\hline \multirow[t]{4}{*}{$\begin{array}{l}\text { Seagrass beds } \\
\text { (Zostera } \\
\text { spp.) }\end{array}$} & $\begin{array}{l}\text { France, Thau lagoon, } \\
\text { Mediterranean }\end{array}$ & $\begin{array}{l}\text { Increased water clarity caused } \\
\text { by the uptake of particulate } \\
\text { material and phytoplankton } \\
\text { by } C \text {. gigas and mussel } \\
\text { aquaculture, is thought to } \\
\text { have enabled Zostera to grow } \\
\text { in deeper areas of the lagoon }\end{array}$ & Deslous-Paoli et al. (1998) \\
\hline & $\begin{array}{l}\text { USA, Washington, } \\
\text { Willapa Bay }\end{array}$ & $\begin{array}{l}\text { General pattern of reduced } \\
\text { density and shoot size of the } \\
\text { native seagrass } Z \text {. marina on } \\
\text { cultured } C \text {. gigas beds }\end{array}$ & Tallis et al. (2009) \\
\hline & $\begin{array}{l}\text { USA, Washington, } \\
\text { Willapa Bay }\end{array}$ & $\begin{array}{l}\text { Shoot density and cover of } Z \text {. } \\
\text { marina declined with } \\
\text { increasing oyster density, } \\
\text { attributed to space } \\
\text { competition; this competition } \\
\text { can generate impacts above } \\
\text { thresholds of } 20 \% \text { oyster } \\
\text { cover. At low densities, } C \text {. } \\
\text { gigas has little impact, } \\
\text { however oyster cover }>50 \% \\
\text { is impenetrable to seagrass }\end{array}$ & Wagner et al. (2012) \\
\hline & $\begin{array}{l}\text { USA, Washington, } \\
\text { Willapa Bay }\end{array}$ & $\begin{array}{l}\text { Immediately seaward of the } C \text {. } \\
\text { gigas zone and amongst } \\
\text { adjacent } Z \text {. marina beds, } \\
\text { benthic diversity was greatest } \\
\text { below the } C \text {. gigas beds, yet } \\
\text { fish and pelagic invertebrates } \\
\text { were more abundant within } \\
\text { seagrass }\end{array}$ & Kelly et al. (2007) \\
\hline \multirow[t]{4}{*}{$\begin{array}{l}\text { Subtidal } \\
\text { sediments }\end{array}$} & $\begin{array}{l}\text { Southern England, } \\
\text { Thames estuary }\end{array}$ & $\begin{array}{l}\text { Seen at least } 3 \mathrm{~m} \text { below } \\
\text { Chart Datum on subtidal } \\
\text { sediments }\end{array}$ & Herbert et al. (2012) \\
\hline & $\begin{array}{l}\text { Northern Ireland, } \\
\text { Lough Foyle }\end{array}$ & Present on subtidal sediments & Herbert et al. (2012) \\
\hline & Ireland, Lough Swilly & Present on subtidal sediments & Herbert et al. (2012) \\
\hline & $\begin{array}{l}\text { Netherlands, } \\
\text { Oosterschelde estuary }\end{array}$ & $\begin{array}{l}\text { Settlement observed in } \\
\text { cultivated subtidal Pacific } \\
\text { oyster beds (depth } 2-3 \mathrm{~m} \text { ) } \\
\text { and on adult oysters at } 10 \mathrm{~m} \\
\text { depth }\end{array}$ & Wijsman, pers. comm. \\
\hline
\end{tabular}


Table 1 continued

\begin{tabular}{|c|c|c|c|}
\hline Habitat & Region & Impact & References \\
\hline & Germany, Wadden Sea & $\begin{array}{l}\text { Adults found at } 10 \mathrm{~m} \text { below } \\
\text { low water, however no } \\
\text { juveniles or recruitment } \\
\text { observed. Are often large } \\
\text { individuals or clusters. Most } \\
\text { likely broken off intertidal } \\
\text { reef structures }\end{array}$ & (Reise, pers. comm.) \\
\hline \multirow[t]{2}{*}{$\begin{array}{l}\text { Subtidal } \\
\text { sediments } \\
\text { contd. }\end{array}$} & Wadden Sea & $\begin{array}{l}\text { Sublittoral stocks estimated as } \\
\text { occupying } 700 \text { ha however it } \\
\text { is unclear whether this is as a } \\
\text { result of recruitment }\end{array}$ & $\begin{array}{l}\text { Kater et al. (2002); Smaal } \\
\text { et al. (2005) }\end{array}$ \\
\hline & Sweden & $\begin{array}{l}\text { Pacific oysters found at depths } \\
\text { from } 1-9 \mathrm{~m}\end{array}$ & Dolmer et al. (2014) \\
\hline \multirow{2}{*}{$\begin{array}{l}\text { European } \\
\text { native flat } \\
\text { oyster } \\
\text { Ostrea } \\
\text { edulis }\end{array}$} & Wadden Sea & $\begin{array}{l}\text { Overlap with native oyster not } \\
\text { expected as it is sublittoral }\end{array}$ & Reise (1998) \\
\hline & $\begin{array}{l}\text { Southern England, } \\
\text { Poole Harbour }\end{array}$ & $\begin{array}{l}\text { Found to settle on shells and } \\
\text { living } C \text {. gigas }\end{array}$ & Authors observation \\
\hline Fish & $\begin{array}{l}\text { USA, Washington, } \\
\text { Willapa Bay }\end{array}$ & $\begin{array}{l}\text { Immediately seaward of the } C \text {. } \\
\text { gigas zone and amongst } \\
\text { adjacent } Z \text {. marina beds, fish } \\
\text { were much more abundant } \\
\text { within the seagrass }\end{array}$ & Kelly et al. (2008) \\
\hline \multirow[t]{4}{*}{ Birds } & Wadden Sea & $\begin{array}{l}\text { Species that have previously } \\
\text { relied on mussels (e.g. Eider } \\
\text { duck, Somateria mollissima), } \\
\text { may not be able to feed on } \\
\text { the oysters due to their size, } \\
\text { shell thickness and } \\
\text { cementation }\end{array}$ & $\begin{array}{l}\text { Nehring et al. (2009); } \\
\text { Scheiffarth et al. (2007) }\end{array}$ \\
\hline & $\begin{array}{l}\text { Netherlands, } \\
\text { Oosterschelde }\end{array}$ & $\begin{array}{l}\text { Herring gull (Larus argentatus) } \\
\text { and Eurasian oystercatcher } \\
\text { (Haematopus ostralegus) are } \\
\text { reported to feed on } C \text {. gigas }\end{array}$ & $\begin{array}{l}\text { Cadée }(2008 \mathrm{a}, \mathrm{b}) ; \text { Troost } \\
\quad(2010)\end{array}$ \\
\hline & Wadden Sea & $\begin{array}{l}\text { Colonisation of } M \text {. edulis beds } \\
\text { by } C \text {. gigas had a positive } \\
\text { impact on feeding rates of the } \\
\text { Eurasian oystercatcher and } \\
\text { the Eurasian Curlew } \\
\text { (Numenius arquata) }\end{array}$ & Markert et al. (2013) \\
\hline & Argentina & $\begin{array}{l}\text { Number of birds (two gulls and } \\
\text { four wading bird species) } \\
\text { was greater amongst } C \text {. gigas } \\
\text { compared to control areas. } \\
\text { Foraging rate of two species } \\
\text { was higher amongst oysters, } \\
\text { whereas in other two species } \\
\text { there was no difference with } \\
\text { control plots }\end{array}$ & Escapa et al. (2004) \\
\hline
\end{tabular}

Impacts from cultivated stocks are included where considered relevant 
Fig. 1 C. gigas reef establishing on a chalk rocky shore in Kent, south east England (Photo: W. McKnight)
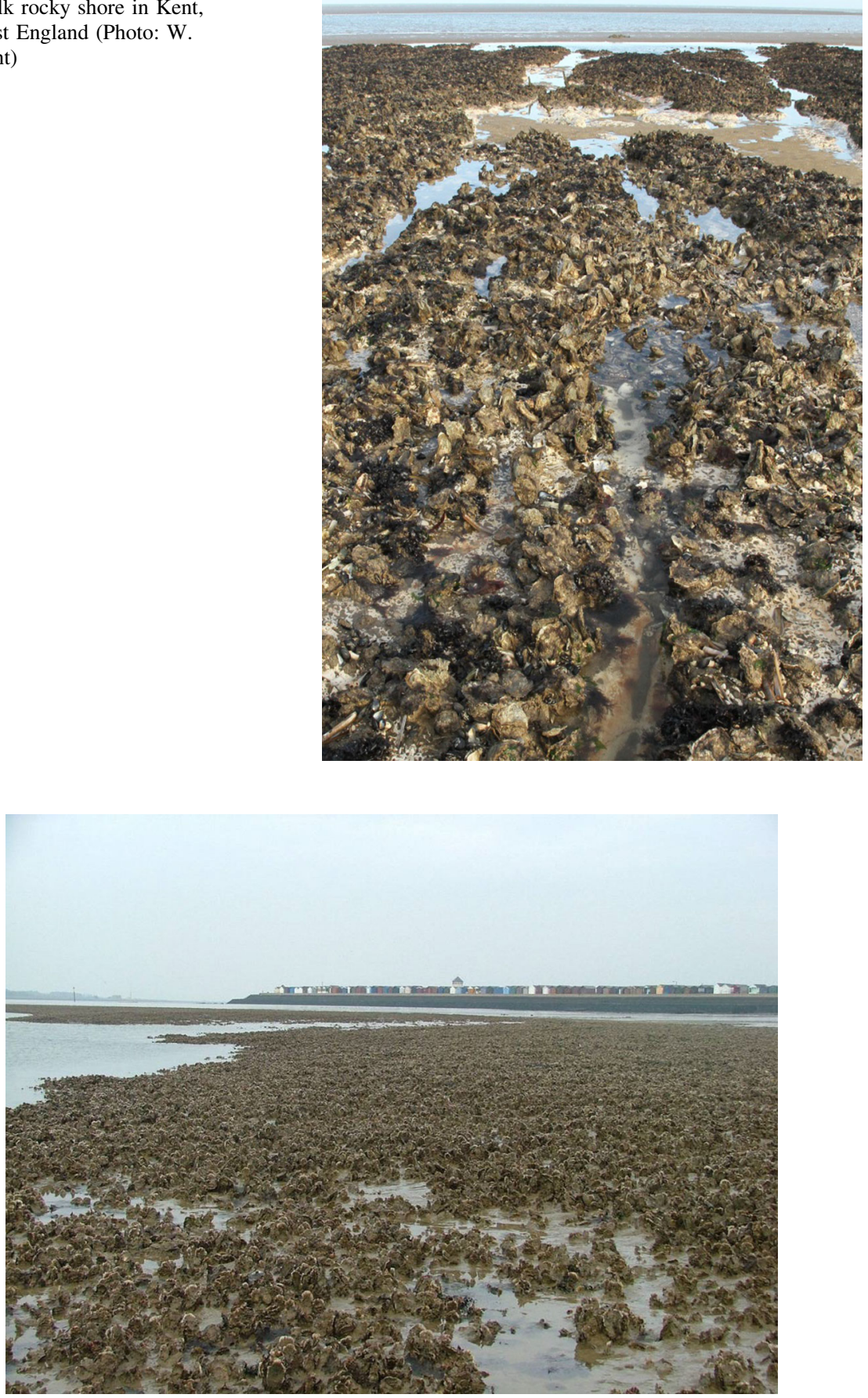

Fig. 2 Wild $C$. gigas reef that has established on intertidal mud on the Blackwater estuary at Brightlingsea (UK) in 2008 (Photo: M Gray) 


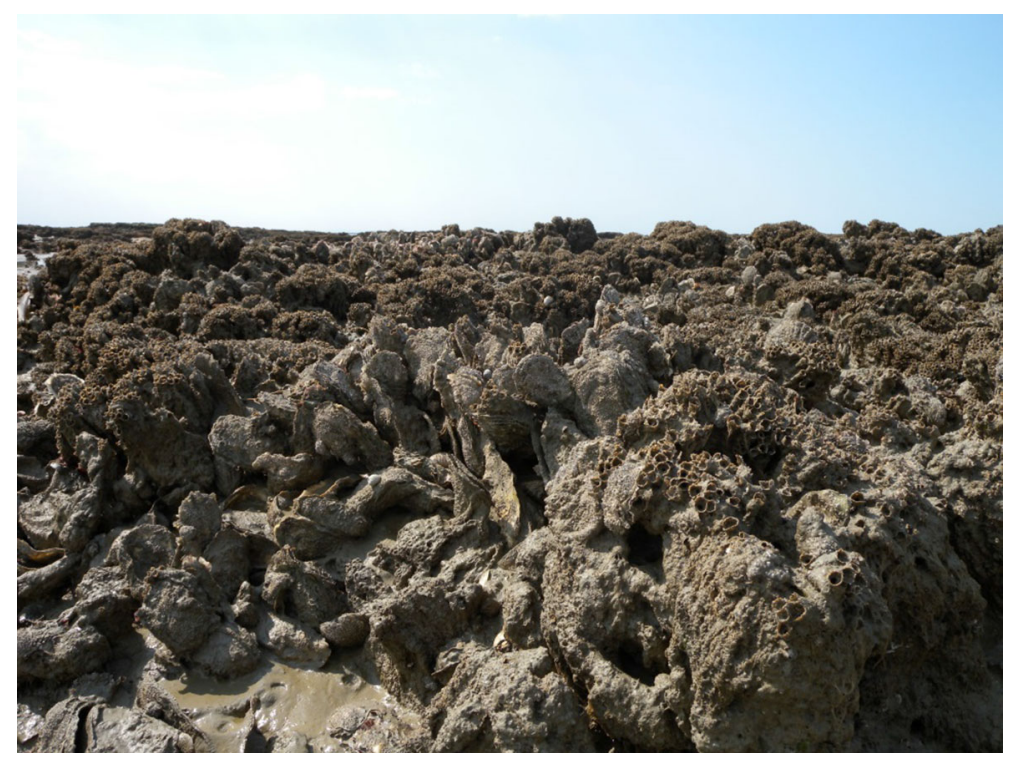

Fig. 3 Wild settlement of C. gigas on reef of Sabellaria alveolta. Bay of Mont-Saint Michel (France) (Photo: N. Desroy)

with high settlement of wild C. gigas (Markert et al. 2010), yet increasingly unsuitable habitat chemistry and anoxia associated with high rates of decomposition of biodeposits and microbial respiration is likely to be responsible for the suppression of species diversity at very high levels of $C$. gigas cover (Green et al. 2012; Green and Crowe 2013, 2014). Due to a sediment-free upper part of the reef and more turbulent current flow, species richness was significantly greater amongst the oyster beds compared to mussels and some faunal species were exclusively found on oyster beds, particularly anemones and suspension feeders (Markert et al. 2010). Higher species survival amongst the more complex oyster reef structure and bio-deposition of sediments was also thought to explain differences in species richness (Kochmann et al. 2008).

Several studies on soft-sediment and rocky intertidal habitats have shown that species diversity can be greater amongst aggregations of wild Pacific oysters compared to the native habitat in which the oysters settle (Table 1). Although there appear to be significant negative impacts on some native species of conservation concern (e.g. Sabellaria reefs) to date there is no evidence for total displacement of any species in Europe. Although there may be beneficial effects of wild settlement on some coastal bird species (Cadée 2008a, b; Scheiffarth et al. 2007; Markert et al. 2013), there remains uncertainty on negative effects on others. The nature and scale of impact and engineering of Pacific oysters is dependent on the type of habitat that is colonised (Padilla 2010) and on the stage of invasion; a low density of scattered individual oysters may have little or no impact on biodiversity at regional scales. Yet at local-scales, the oysters can facilitate grazers (Ruesink 2007) and can modify the thermal regime of the habitat (Padilla 2010). Species interactions also influence community resistance to invasion. While there is evidence that a higher native diversity of sessile invertebrates can suppress a potential invader through competition for space (Olyarnik et al. 2009), this can be alleviated by facilitation, e.g. by the provision of space for secondary settlement on oyster shells. 
Crassostrea gigas reefs may compensate for the loss of ecological function of mussel beds in the Wadden Sea (Markert et al. 2010; Troost 2010). Yet comparatively little evidence is available for impacts of wild settlement of $C$. gigas on ecosystem functioning. In field experiments in Lough Swilly, Ireland, (Green et al. 2012; Green and Crowe 2013) C. gigas significantly altered several biogeochemical properties and processes, including fluxes of important limiting nutrients, and microbial assemblages and activity. Sedimentwater fluxes of $\mathrm{NH} 4+$ and $\mathrm{Si}(\mathrm{OH}) 4$ and benthic turnover rates increased with increasing cover of oysters in mudflats but decreased at the greatest cover of oysters in mussel-beds (Green and Crowe 2013). Community respiration $\left(\mathrm{CO}_{2}\right.$ flux) increased with the greatest cover of oysters on mudflats and among mussels. At $100 \%$ cover compared to $0 \%$ cover, there was significantly greater total microbial activity, chlorophyll content and $\mathrm{CO}_{2}$ and $\mathrm{CH}_{4}$ emission from sediments (Green et al. 2012). At $10 \%$ cover, C. gigas increased the concentration of total oxidised nitrogen and altered assemblages of ammonia oxidisers and methanogens. At any cover of $C$. gigas, concentrations of pore-water $\mathrm{NH} 4+$ were greater than in areas of mudflat without $C$. gigas. Thus $C$. gigas may alter ecosystem functioning not only directly, but also indirectly by affecting the microbial communities that underpin ecosystem processes.

The water-filtering capacity of native suspension feeding benthic species is known to have a significant controlling effect on phytoplankton and nutrient levels in estuarine waters (Hily 1991). It is considered that the high filtration rate of C. gigas may also have potential to affect trophic dynamics within ecosystems by consuming high quantities of suspended particles and plankton (Ruesink et al. 2005; Troost et al. 2009; Troost 2010) that could also affect water quality. Cultivated $C$. gigas can reduce the carrying capacity and compete trophically with commercial mussel production (Wijsman et al. 2008). Modelled simulations of nutrients, oyster growth and phytoplankton in the Baie des Veys estuary in northern France showed significant depletion of phytoplankton above areas where $C$. gigas is cultivated, with consequences for the spatial distribution of plankton across the bay (Grangeré et al. 2010) and potential impacts on native suspension feeding species. Field investigations of the impact of extensive cultivated $C$. gigas on chlorophyll concentrations in Wallapa Bay, USA, supported modelled scenarios and showed that although oyster filtration rates were lower than laboratory measurements, the oysters can exert top-down control on phytoplankton production within estuaries (Wheat and Ruesink 2013). Yet isotopic analysis on the diet of wild Pacific oysters on rocky shores along an estuarine gradient in the Bay of Brest (Marchais et al. 2013) found that benthic biofilms and resuspended macro algal detritus, rather than phytoplankton, constituted the greatest proportion of the diet. The $1 \mathrm{~m}$ height difference between oysters cultivated on trestles and benthic wild oysters may explain variance in the proportion of benthic $\mathrm{v}$ pelagic sources (Marchais et al. 2013), so caution is necessary at extrapolating impacts of aquaculture to the issue of wild settlement. A higher near-bed turbulence caused by the roughness of Pacific oyster reefs, together with the high water filtration capacity of the oysters, may increase food intake rate (Troost et al. 2009; Troost 2010).

Local coastal typology and hydrodynamics are also likely to be influential on water filtration. However, on a regional and landscape-scale it remains unclear what if any impact wild settlement of $C$. gigas will have on ecosystem function. It has been argued that, unlike other coastal developments and stressors, bivalve aquaculture on the Pacific coast of North America does not remove significant habitat area, result in a decline in water quality, nor is there any evidence for causing a shift to alternate states (Dumbauld et al. 2009). Wild settlement and reef formation of Pacific oysters may yet be considered beneficial in some contexts; providing supporting processes such as erosion control (Borsje 
et al. 2011) and ecosystem services in addition to food provision, such as the use of shells in construction and coastal defence (Piazza et al. 2005; Scyphers et al. 2011; Herbert et al. 2012).

We have not specifically considered in detail the impact of $C$. gigas introductions on the spread and ecological and economic damage caused by the 'hitch-hiking' of other nonnative species, parasites and pathogens. Potentially, C. gigas reef formation might facilitate their colonisation by creating a suitable habitat for their establishment. In the list of species colonising C. gigas reefs on rocky and muddy habitats in Brittany (Lejart and Hily 2011) there are only two non-native species that are not present in un-colonised habitat beyond the reefs; the barnacle Austrominius modestus (as Elminius modestus), that had colonised the shells of $C$. gigas on the muddy shore and the ascidian Steyla clava that had colonised the reefs but were not found in either natural habitat. However there are concerns that the invasive brush-clawed crab Hemigrapsus takanoi has that has recently been recorded in European C. gigas reefs (Wood et al. 2015) will prey on native Carcinus maenas (Dauvin et al. 2009; van den Brink et al. 2012). As C. maenas is an important prey species for some coastal bird species, these interactions would benefit from further investigation.

\section{Habitat transformation and homogenisation}

There is a risk that the introduction of invasive non-native species might result in taxonomic homogenisation of the biota of habitats, as similarity of species composition increases following the combined effects of invasion and extinction of native species (McKinney and Lockwood 1999). Elton (1958) considered the business of culture and transportation of oysters, including $C$. gigas, around the globe was the greatest agency for the spread of non-native species, including oyster pests. This, he asserted, would result in faunas becoming similar across regions.

It is possible that because $C$. gigas can colonise large areas of a wide variety of intertidal habitats, it will result in the biotic homogenisation of intertidal habitats at local and regional scales. In the Oosterschelde estuary (Netherlands), C. gigas reef has colonised the lower shore and currently represents approximately $8 \%$ of the entire intertidal habitat (Smaal et al. 2009). Of the 115 taxa that were recorded within C. gigas reefs that had formed on rock and mud habitats in Brittany (Lejart and Hily 2011) only 11 were common to both reefs. However the reef that formed on the muddy habitat became dominated by carnivores at the expense of suspension feeders. In terms of the proportion of different trophic groups, this reef became comparable to the $C$. gigas reef that colonised the rocky habitat and the rock itself. These findings support those of Markert et al. (2010) who also observed the increasing dominance of carnivores (e.g. crab Carcinus maenas) on C. gigas reefs that had colonised mussel beds. Therefore although local taxonomic homogenisation might be currently considered low ( $\sim 10 \%$ ), functional homogenisation (Olden 2006) may become greater.

Large areas of mudflats in the Wadden Sea and rocky shore on the Atlantic coast of France have been transformed to non-native oyster reefs. The spatial dominance of large filter feeding organisms and higher filtration capacity of the oyster reef differs considerably to shores characterised by algae, grazers (e.g. limpets) and other filter feeders (e.g. barnacles) on a rocky reef. Dense wild settlement of $C$. gigas could therefore transform some protected habitats from a functional state in which they were originally designated, to a new functional state. Although the functional state of some rocky shores might be significantly transformed through the colonisation of $C$. gigas, the same may not necessarily be true for habitats consisting primarily of filter-feeders, such as mussel beds, as they may 
simply be replaced by an equivalent filter feeding species that can accommodate a similar associated fauna. On soft-sediment shores in the Wadden Sea, the distribution of C. gigas can overlap with native filter-feeding bivalve species such as Macoma balthica, Scrobicularia plana and Cerastoderma edule (Troost 2010). Yet although expansion of the oyster reef could be expected to have an impact on the diversity and abundance of native softsediment species on the lower shore, these species also occur above the tidal level of $C$. gigas reef development, although the extent of habitat overlap is likely to depend on locality. The spatial extent of the impact of wild settlement on the diversity and functionality of native habitats is therefore difficult to determine.

While there is evidence of local impacts of wild $C$. gigas on species diversity and ecosystem functioning across a range of intertidal habitats there is less evidence of wild settlement on the ecological integrity of protected areas. Scaling-up impacts through spatial modelling may be beneficial; however it is also necessary to undertake field studies due to the context dependency of some impacts. Clearly the impact on sublittoral biodiversity also requires further investigation. Considering that the conservation of migratory birds is of great importance in Europe there has been relatively little investigation on the impact of Pacific oysters on behaviour and fitness. This is important as this could influence the type and scale of management interventions in areas affected by extensive wild settlement.

\section{Policy framework and management measures}

Although species diversity of a non-native oyster reef might be greater than the native habitat and include higher densities of particular species (Lejart and Hily 2005, 2011; Markert et al. 2010), for areas protected under the EU Habitats Directive, it is the fundamental alteration in type and variety of habitats or biotopes that is important. The threshold level and area of impact whereby a site might be considered to have changed has not been quantitatively determined, and to our knowledge has not been legally tested or previously considered for a non-native species. However, as far as the EU Habitats Directive is concerned, of critical importance to whether a site is classified as being in favourable condition is whether the 'integrity' of the whole designated site is transformed. The integrity of the site has been defined as 'the coherence of its ecological structure and function, across its whole area, that enables it to sustain the habitat, complex of habitats and/or the levels of populations of the species for which it was classified' (European Commission 2000). Broad-scale changes and the transformation of species communities or biotopes might be interpreted as compromising the integrity of the designated site. In Britain, conservation agencies have concluded that even the loss of considerably less than $1 \%$ of designated sites could be significant and in some cases would adversely affect site integrity (Hoskin and Tyldesley 2006), though not specifically for non-native species. The risk of ecological impacts of wild settlement in a warming world has unnerved conservation agencies and the aquaculture industry. For example, in the UK and Ireland, plans to develop a new Pacific oyster farm within or in the vicinity of a protected area may need to satisfy agencies and authorities that the proposal will not have an adverse effect on habitats and species. In Europe, there are various stages in the 'Environmental (Appropriate) Assessment' process; importantly however, the Likelihood of Significance of the Impact and the Impact on the Integrity of the Site will need to be determined. Examples of 'Significant Impacts' provided by the European Commission and UK agencies are shown in Table 2. 
Due to wide ranging impacts of non-native species, provisions are included in EU policies aimed at the protection of ecosystems and sustainable use of natural resources. However, species that have had a long history of aquaculture and which are of economic value are excluded from the scope of the EU Regulation on the prevention and management of the introduction and spread of invasive alien species (EU) No 1143/2014, as they can be listed within Annex IV of Council Regulation of the European Commission concerning use of alien and locally absent species in aquaculture (EC) No 708/2007 (ECASR). Article 4 of this Regulation confers a general obligation for Member States to implement measures to avoid adverse effects to biodiversity "which may be expected to arise from the introduction or translocation of aquatic organisms and non-target species in aquaculture and from the spreading of these species into the wild". Yet under EC-ASR, EU Member States (European Commission 2016b) have discretion on whether to impose limits under Annex IV, for example if Pacific oysters have not previously been used in aquaculture.

Invasive species are generally recognized as posing a risk to achieving good ecological status under the EU Water Framework Directive (WFD) and may preclude the area from attaining a high status water body designation. Similarly, invasive species are among the indicators to be used to assess environmental status under the EU Marine Strategy Framework Directive (MSFD 2008). Given these constraints, an authority may prohibit the transfer of oysters to an area in order to maintain or improve the status of a particular site. It should be noted, however, that the presence of Pacific oysters per se does not necessarily mean that action will be taken, as it is the impact of the species on the habitat and not the presence that is a concern. As the Pacific oyster is a non-native species in Europe it is subject to Article 22(b) of the Habitats Directive which requires Member States to "ensure that the deliberate introduction into the wild of any species which is not native to their territory is regulated so as not to prejudice natural habitats within their natural range or the wild native fauna and flora and, if they consider it necessary, prohibit such introduction". However pathways for introduction of Pacific oysters other than aquaculture have also been implicated. Wild establishment as a direct result of introductions into marinas, harbours and ports from boat traffic as fouling or entrained larvae are as yet unproven but suspected. In the UK there are coastal regions where wild settlement is occurring that is distant from Pacific oyster production (Herbert et al. 2012; Smith et al. 2015). Moreover in Lough Foyle on the north coast of Ireland, wild oysters were shown to

Table 2 Examples of 'significant impacts' on European Natura 2000 sites (English Nature 1999; European Commission 2001)

Alteration of community structure

Reduction in area of habitat/biotope or species for which the site was originally notified

Causes on-going disturbance to species or habitats

Presents a barrier between isolated fragments of native habitats, or reduces the ability of the site to act as a source of new native colonisers

Causes direct or indirect change to the physical quality of the environment (including the hydrology) or habitat within the site

Causes direct or indirect damage to the size, characteristics or reproductive ability of populations on the site Alter the vulnerability of populations/habitats to other impacts 
be genetically different from current stock obtained from local oyster farms (Kochman et al. 2012). While this may reflect changes in broodstock through time, it is also possible that there were other pathways of introduction (Kochman et al. 2012).

Pacific oysters appear vulnerable to invertebrate predators (Syvret et al. 2008; Troost 2010), parasites (Troost 2010) cold winters (Buettger et al. 2011) and smothering by estuarine sediments (N. Miezkowska, pers. comm.). Mass mortality events across Europe caused by the ostreid herpesvirus 1 (OsHV-1) (Cotter et al. 2010; Segarra et al. 2010; Morrissey et al. 2015) may result in temporal and spatial fluctuations of wild settlement in some areas; moreover there is moderate confidence that outbreaks of some variants of the virus may increase with rising temperatures (Rowley et al. 2014). Yet the evidence suggests that frequent and dense settlement over extensive areas of certain habitats, if unmanaged, could put at risk the ecological integrity of protected sites. Within the existing European policy framework, widespread eradication and the prohibition of $C$. gigas aquaculture is highly unlikely as it would considerably reduce the economy of large areas of coastal Europe (Fig. 5). In some regions of France, wild spat has now become so economically important for the oyster industry (P Goulletquer, pers. comm.) that it is protected and carefully managed by fisheries administrations. Moreover the environmental sensitivity and impracticability of removing large areas of wild settlement has led some countries to adopt the species as naturalised (e.g. Netherlands, (Drinkwaard 1999). Yet under the EU Marine Strategy Framework Directive (MSFD 2008) member states are required to implement a surveillance programme and evaluate a programme of measures to reduce the impact of non-native species. Although $C$. gigas is listed as one of the worst 100 Alien species (DAISIE 2016) there appears to be no technical or political consensus on its environmental impact and management across Europe.

\section{Risk assessment and management measures}

Risk assessment protocols for the introduction of non-native species recommend a detailed analysis and review of possible ecological, genetic and disease impacts of the proposed introduction and the likelihood of spread within and beyond the release site (ICES 2005; Copp et al. 2016a, b). In the context of rising biomass and recruitment of Pacific oysters, these can include specific impacts on native species, such as competition for space with other species, modifications to trophic structure of habitats and sediment, impacts on protected sites and endangered habitats and economic considerations. In the UK, C. gigas is classified as presenting a 'medium' risk to nature conservation as the species could become invasive and have an impact on sensitive habitats and species (Sewell et al. 2010). In Scandinavia, separate risk assessments have been conducted for different habitats under IPCC climate scenarios (Dolmer et al. 2014). For example under both short-term and longterm climate scenarios, it was considered that Pacific oysters would have a 'moderate' ecological impact on littoral biogenic reefs in low energy areas (little or no tide, little current and low wave exposure) and a high ecological impact in high energy areas (large tidal fluctuations, strong currents and high wave exposure). Degrees of uncertainty associated with these impacts under different scenarios are also given. An application of the European Non-native species in aquaculture Risk Assessment scheme (ENSARS), a modular scoring scheme developed for evaluating the risk of introduction, establishment, dispersal and impact of species under EC-ASR, rated Pacific oyster as having an overall 'medium' risk (Copp et al. 2016a, b). This was carried out by two French assessors with metropolitan France as the risk assessment area, for which the confidence level of assessment for 'introduction' and 'impact' was rated as 'high'. 
In circumstances where the eradication of species that are potentially damaging to ecosystems and the economy is not possible then management measures, that are proportionate to the impact on the environment, should be proposed (European Union 2014). The development of management measures to control the spread of invasive species in open marine ecosystems present unique technical, social, economic and political challenges. Yet there has been progress in the development of decision-making frameworks and protocols that help to assess the risk of control programmes and the effectiveness of different options (Bax et al. 2001; Thresher and Kuris 2004). These can range from physical removal of the pest species to commercial utilization, the application of biocides and biological control agents, genetic approaches and efforts to rehabilitate and improve the biological resistance of the environment (Thresher and Kuris 2004). The level of ecological and socio-economic risk of wild settlement and impact may not have reached its maximum in all regions. However, there is some inevitability that, should predictions of continued warming under the IPCC scenarios be realised, the frequency and magnitude of settlement will increase, causing existing populations to rise and new populations to become established. As the level of environmental and ecological risk varies with locality then a local or regional approach to the management of wild Pacific oyster settlement is likely to be more effective than broad-scale measures that in some areas may currently be irrelevant. Figure 5 summarises the decision making process that supports this assertion and provides examples of management options that could be selected in a specific regional context.

Here we review various approaches to reduce the risk of wild settlement of $C$. gigas in protected areas and negative impacts of its establishment.

\section{Marine planning and husbandry}

The rate and extent to which $C$. gigas might become established will depend on the 'invasion (or propagule) pressure' and the biological resistance of the receiving system (Williamson 1996; Rilov and Crooks 2009). Invasion pressure and larval supply will be determined by the frequency of introduction, the size and fecundity of introduced breeding stock and the physical characteristics of the water body, including hydrodynamics that will determine larval transport.

It is generally accepted that wild settlement is dependent on the attainment of critical water temperature thresholds for oyster gametogenesis, spawning and larval development (Miossec et al. 2009; Dutertre et al. 2010). In Europe, the frequency at which temperature thresholds are now reached has increased within the past two decades (Dutertre et al. 2010). The use of 'degree days' (the annual number of days when temperatures meet thresholds for conditioning (gametogenesis), spawning ${ }^{1}$ and recruitment ${ }^{2}$ ), for assessing 'wild settlement risk' is considered a useful initial screening tool when planning for, or relicensing C. gigas aquaculture developments (Syvret et al. 2008). Yet there is uncertainty with respect to acclimatisation to local temperatures, physiological adaptation and duration of the larval development phase in response to available nutrition. Notwithstanding site anomalies and the requirement for accurate temperature measurements, this risk-based management has been incorporated into a 'Pacific Oyster Protocol' that has become acceptable to some in the UK industry and regulators (Syvret et al. 2008; Woolmer 2009).

\footnotetext{
${ }^{1} 600^{\circ}$ days for conditioning and spawning $\left(>18{ }^{\circ} \mathrm{C}\right.$ assumed trigger for spawning).

$2825^{\circ}$ days required to achieve larval metamorphosis.
} 
Through spatial planning, it could be possible to manage the scale of aquaculture operations and introduce husbandry restrictions within each water body to minimise larval production, survival and shore settlement. Water bodies at particular risk could be identified using models of environmental characteristics associated with $C$. gigas establishment (Kochmann et al. 2013) and hydrodynamic models (Brandt et al. 2008; North et al. 2008) that could be adapted to investigate larval transport and dispersal. Assessment of the physical characteristics, flushing characteristics, water residence time and temperature regime of associated water bodies could enable the identification of water bodies that, due to their physical characteristics, might be particularly vulnerable to wild settlement should cultivated (reproductively active) biomass exceed a particular threshold. In this way, restrictions on aquaculture could be appropriately targeted rather than widely applied.

Pacific oysters are cultivated in a variety of ways depending on exposure, substratum and degree of siltation (Miossec et al. 2009). Studies on the impact of oyster husbandry have focussed on variation in growth and mortality, rather than reproductive condition and development. In a review of research on the French Atlantic coast (Goulletquer et al. 1998) and south-west England (Robbins 2005), Syvret et al. (2008) concluded that 'parc' or onbottom culture might result in a greater level of reproductive potential compared to offbottom cultivation in bags on trestles, though the type of cultivation that is appropriate and employed will be dependent on local factors related to the degree of shelter and hydrodynamics. Studies in North Wales have shown that growth rate can be greater at lower tidal levels (Spencer et al. 1978) and there is evidence from the Atlantic coast of France that reproductive condition (gonadosomatic index) increases with immersion time and in animals greater than 2 years old (Goulletquer et al. 1987). This would suggest that high shore cultivation would result in reduced spawning potential. However contradictory findings were obtained in North Wales by King et al. (2006) who found gonad development to be greater at high shore compared to low shore sites, though oysters showed little maturation and spawning. Experiments in British Columbia on the growth rate and mortality of oysters suspended at different depths within the water column (Cassis et al. 2011) showed that these parameters were affected by depth, temperature, freshwater input, phytoplankton abundance and assemblage composition. On the west coast of Ireland differences in the condition of intertidal and subtidal oysters varied between sites and among months (R. Mag Aoidh, unpubl.data). Experimental studies (Chavez-Villalba et al. 2003) showed that C. gigas had flexible reproductive patterns depending on food variability. Clearly the issue of reproductive condition and likelihood of spawning is complex and influenced by several site specific factors and temporal variability.

Aggressive and invasive outbreaks of wild settlement can only be effectively managed if good quality data is available and forthcoming. Frequent surveys are important and necessary to assess the distribution and density of wild settlement. In New South Wales (Australia), up to date distribution data has been used to inform Risk-based Pacific Oyster Regulation and movement controls between estuaries have been implemented to minimise the spread of the species in the wild (NSWDPI 2015). As a requirement for licensing in Wales, oyster growers have been asked to remove any signs of wild settlement (Herbert et al. 2012).

\section{Triploidy}

One of the only feasible modes of containment for non-native species within the aquaculture industry is reproductive sterility (Allen and Guo 1996). A method of achieving sterility is induced triploidy, a condition in which a cell or organism has three sets of 
chromosomes as opposed to the normal two sets of chromosomes. The triploid condition can confer a level of sterility through rendering the oysters unable to produce viable gametes and hence preventing spawning and wild settlement. The likelihood of triploid oysters producing viable offspring has been reported to be extremely low (Guo and Allen 1994) and, by all practical measures, zero (Allen and Guo 1996). Although considered by the authors as an over-estimate Suquet et al. (2016) has calculated that the reproductive potential of triploid Pacific oysters is close to $0.06 \%$ that of diploid individuals. A further issue relates to the stability of the triploid condition. In the USA, a trial in which 'certified triploid' oysters were placed in the York River was halted when it was discovered that about $20 \%$ of the oysters had a 'dual cell state', containing both diploid and triploid cells (referred to as 'mosaics') (Gottlieb and Schweighofer 1996; Allen and Guo 1996; Allen et al. 1999). Investigating the chromosomal stability of triploid populations in the USA, Allen et al. (1999) reported that over a period of 2 years, there was a progressive reversion with more diploid cells accumulating over time. The frequency of reversion in chemically induced triploids had been two to three times higher than in mated triploids and the frequency of reversion also varied between grow-out sites, with harsher environments potentially exacerbating the problem of reversion (Allen et al. 1999). Jouaux et al. (2010) showed that in about $25 \%$ of mated triploids, the process of gamete production closely resembled that of diploid oysters. Triploid oysters cannot be considered to be "non-reproductive' (Normand et al. 2009) and there is evidence that gonad development and spawning in triploid C. gigas may be enhanced in unusually hot summers (Normand et al. 2008) which are predicted in current climate change scenarios (IPCC 2014). There is no doubt that there is still a measure of uncertainty concerning the circumstances and risk of reversion, however given the lower reproductive potential of triploid Pacific oysters, they should be considered as a potential measure for biological containment. The relative reproductive potential of triploids is increased when they are crossed with diploids (Gong et al. 2004), so their introduction into regions where there is wild diploid stock is unlikely to be effective at containing outbreaks. However in regions where diploid stocks are zero or very low, there may be merit in using triploid oysters as a practical measure to reduce the probability of wild settlement. It has been shown that there is no significant difference in growth when the growing conditions of the area are poor (Nell 2002). Yet in the UK, some growers are concerned about high growth rates of triploids and the cost of seed (Herbert et al. 2012), so broad acceptance within the industry might be difficult to achieve (Herbert et al. 2012). Nevertheless, triploid C. gigas are used widely in Australia (O'Connor and Dove 2009), France (Normand et al. 2008), the USA and Ireland and this approach may become important for the containment of oysters in culture (Guo et al. 2009).

\section{Mechanical control}

Total eradication is not feasible or practical as densities are now so high in some regions that sufficient brood stock is likely to remain and settlement will continue. After extensive establishment of Pacific oysters in the Wadden Sea, there was unanimous agreement that any large scale eradication or control methods would harm other components of the native ecosystem (Reise et al. 2005). In the Oosterschelde estuary, Netherlands, where wild $C$. gigas can reduce the carrying capacity and compete trophically with commercial mussel production, an experimental dredging of 50 ha of intertidal wild oysters and sub-littoral cultivated beds was carried out using mussel dredges (Wijsman et al. 2008). The oysters could be effectively removed and the operation involved 940 boat hours (20 boat hours per 
ha). At one of the dredging sites there was little impact on subsequent oyster settlement and, at a second site, some hard shell debris remained on the mud surface. Oysters subsequently settled on the cleared areas, though there was no monitoring plan and it was concluded that beds should be cleared every 5-7 years to reduce potential competition between oysters and other harvestable shellfish species (Wijsman et al. 2008). Yet most reefs have remained undisturbed (i.e. unfished) since their first mapped appearance in the 1980s (Smaal et al. 2009; Walles et al. 2015). The general consensus of experts in the Wadden Sea is that large-scale dredging would cause considerable habitat damage (Reise et al. 2005; K. Reise pers. comm.). Since the 1990s, spatfalls of C. gigas have increased on the west coast of France and industrial equipment has been used to clear wild beds of $C$. gigas and colonised infrastructure that were competing with cultivated beds (Goulletquer 2009). In shallow ( $<2 \mathrm{~m}$ ) areas of Lake Grevelingen (a saltwater lake in Holland) where the sharp shells of wild Pacific oysters have injured swimmers, the oysters are removed by grabs, and the remaining shells are covered by sand (Wijsman pers. comm.).

The effectiveness of removal of wild $C$. gigas (mean density $<1 \mathrm{~m}^{-2}$ ) has been investigated in Strangford Lough, Northern Ireland (Guy and Roberts 2010). Shells encountered on transects were broken with a hammer during the spring. In the year following the cull, although densities at un-culled sites continued to rise, oyster density at culled sites had dropped by nearly $100 \%$. It is assumed that oysters that were hammered were killed and that there had been no further settlement at these sites. It was concluded that the measure could be beneficial at reducing population expansion in the early stages of invasion. The probability of settlement may be reduced further if shell debris is also removed as this can be attractive to settling larvae (Arakawa 1990; Gutiérrez et al. 2003).

Rocky habitats may present the greatest challenge in terms of management and containment due to difficulties associated with the physical removal of oysters. A pilot trial to hold the advancing line of Pacific oysters has been conducted in Kent, south east England (McKnight and Chudleigh 2015). The objective was to reduce the wild spawning stock that had colonised chalk intertidal platforms and artificial structures and prevent settlement on nearby protected chalk reefs and intertidal mudflats. Using a variety of tools including edging spades, rods, hammer, pliers and safety equipment, over 40,000 oysters were removed during 43 site visits (96 man hours) along three sections of the coast where they had colonised chalk reefs and mussel beds. However it remains to be seen if the rate of wild settlement in this region is reduced. It is anticipated that further work will be undertaken by a volunteer group in the locality (Fig. 4).

\section{Opportunities through hand-collecting and fishing}

Between 1976 and 1981, handpicking was used to reduce the wild stock of Pacific oysters in the Oosterschelde. These attempts failed and the new inhabitant was accepted as belonging to the Dutch fauna (Drinkwaard 1999). Yet recently, local stakeholders have financed a pilot scheme to remove Pacific oysters from selected beaches where their sharp shells cause injury to tourists (P. van Avesaath pers comm). An efficiency study has shown potential for economic exploitation of isolated oysters and profits appear high enough to support future interventions which are being planned in the southern Dutch Delta (P. van Avesaath pers comm). Guided walks to the oyster reefs are also being organised for visitors to collect wild oysters for food (BBC 2015). Depending on a favourable market, it is possible that some effective control on wild Pacific oyster settlement could be possible through regulated fishing and hand-collecting. Both hand-collecting and dredging over soft sediment habitats creates patches of open mud within oyster reefs for bird feeding. 


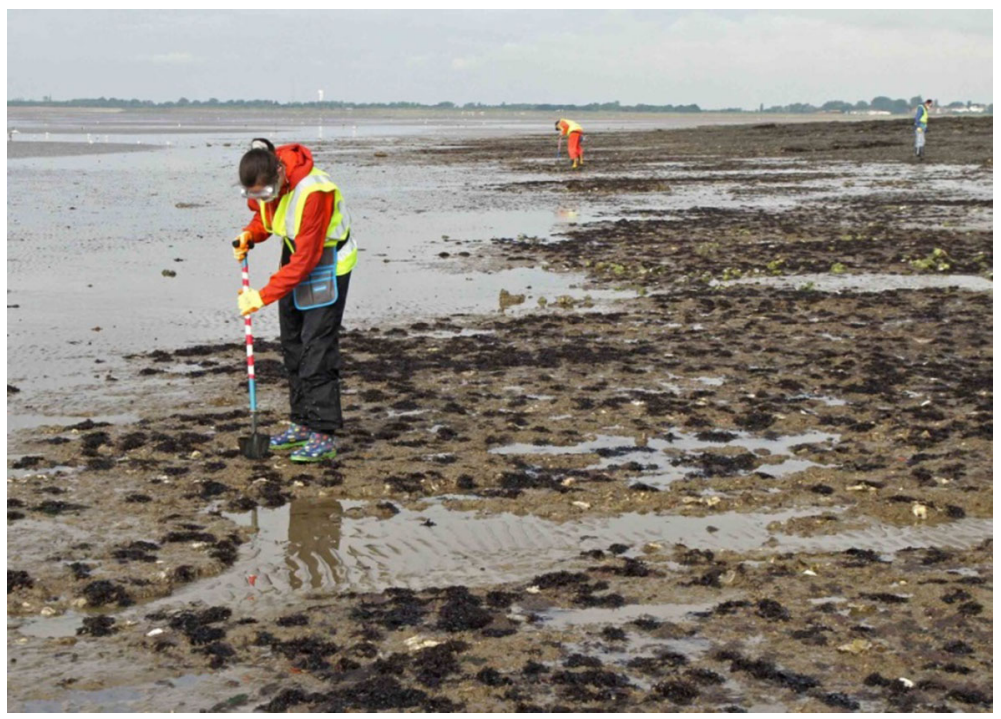

Fig. 4 Hand removal of $C$. gigas by volunteer workers on a protected chalk shore in Kent, south east England (Photo: W. McKnight)

Moreover, the density and spatial arrangement of Pacific oysters has been shown to affect the impact of wild settlement upon the native Australasian oyster Saccostrea glomerata (Wilkie et al. 2013). Although fishing activity creates different impacts and disturbances on intertidal benthic species and habitats (Hall and Harding 1997; Spencer et al. 1998; Kaiser et al. 2001; Piersma et al. 2001) and hand-collecting may disturb bird feeding at low tide (Goss-Custard et al. 2006), it is possible that the extent and intensity of these activities could be managed by acquiring licences. In the Blackwater estuary on the south-east coast of England, large areas of C. gigas 'reef' have been hand-picked 'clean' of wild oysters to create areas for re-laying oyster seed (Herbert et al. 2012). This seed does not grow to maturity to form reef but is either hand-collected or dredged and re-laid in creeks for ongrowing. A variety of wading birds can feed in areas where oysters have been removed and amongst newly laid seed.

Notwithstanding marketing and biosecurity challenges (Humphreys et al. 2014; Schrobback et al. 2014; Ronholm et al. 2016) there is an increasing demand for aquaculture and oyster products (FAO 2016b). As in the Oosterschelde it may be possible to provide financial incentives to support and develop a sustainable industry, particularly where dense reefs have not yet formed, as individual oysters have far greater value than those with distorted shells. For example in ports, harbours and marinas, where fouled vessel traffic is suspected of contributing to wild settlement (Herbert et al. 2012; Smith et al. 2015), harvesting oysters may be a viable way of controlling the stock. Business start-up schemes and fisheries and aquaculture support schemes could be appropriate avenues for support (Fig. 5). 


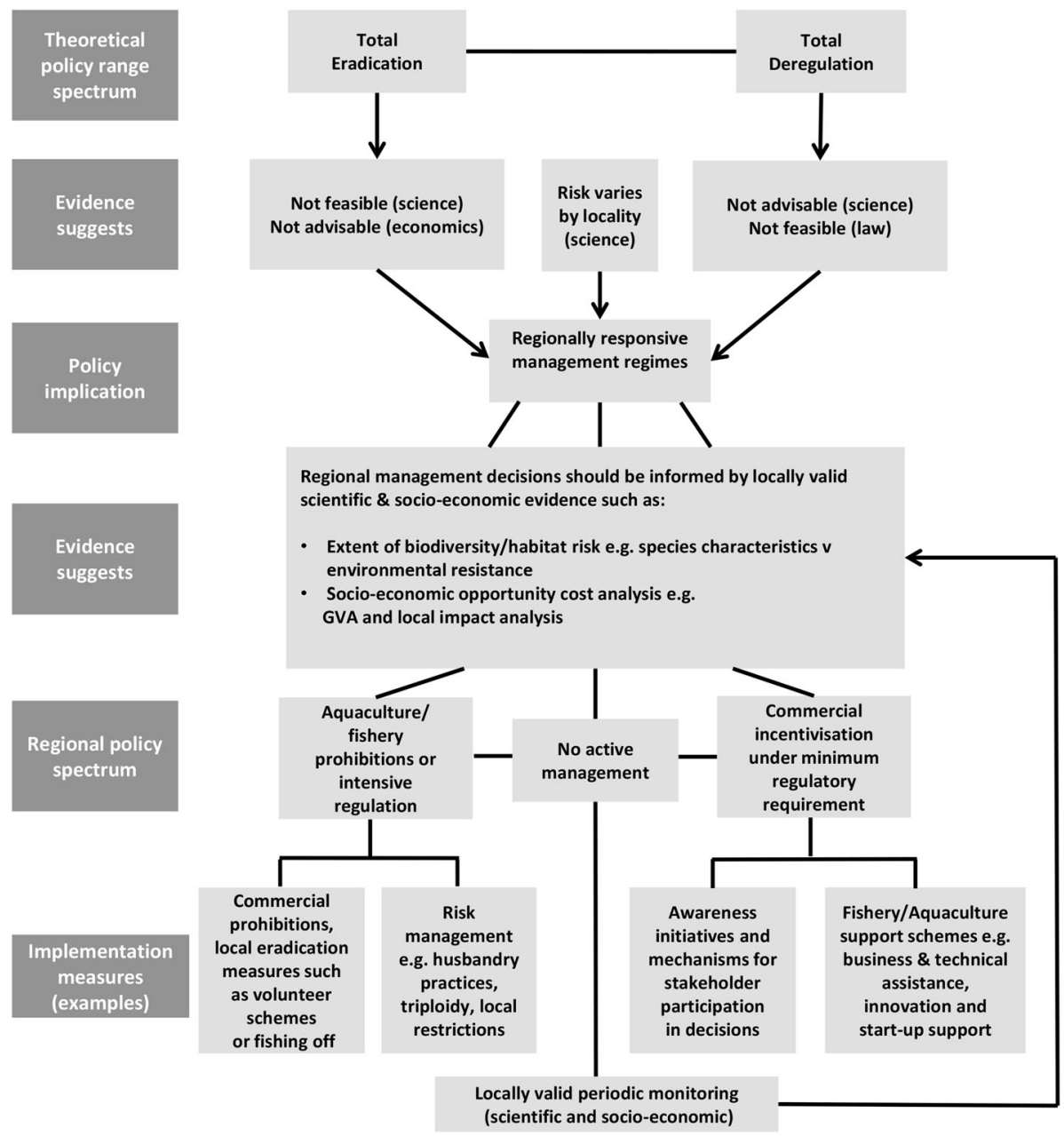

Fig. 5 Potential regional approach to management of wild Pacific oyster settlement [Gross Value Added (GVA) is a measure of direct economic contribution and does not represent the full economic impact of an activity]

\section{Conclusions}

Global climate change presents new challenges and risks with respect to the management and conservation of the marine environment (Hawkins 2012). The biosecurity of marine resources, including all cultivated species, must be given a high priority in view of predicted rises in air and sea temperatures and the increased risk of economic and environmental damage caused by invasions of non-native species. Few could have predicted the enhanced fecundity and growth of wild populations of Pacific oysters in Europe as result of higher temperatures, and the potential and actual environmental impacts. We conclude that in view of the potential risks to biodiversity, all stakeholders, including growers, port and harbour authorities and statutory environmental agencies must engage in regional decision making (Bax et al. 2001) to help minimise any negative environmental impacts of wild 
settlement on features of conservation interest, while at the same time, and within those constraints, maximising opportunities for sustainable industry development. Without stakeholder co-operation and managed interventions, the ecological impacts of wild settlement on species and habitats are likely to be exacerbated (Herbert et al. 2012). To maintain habitats in good condition and protect features of conservation interest it is important to develop strong partnerships between agencies and fisheries; in the Blackwater estuary, fishing interests, nature conservation organisations and the harbour authority are attempting to ensure aggressive outbreaks of wild settlement on mudflats are controlled through localised dredging (Herbert et al. 2012). However the success and continuity of these partnerships requires a vibrant industry, therefore incentives and assistance with marketing of produce might be required to achieve both commercial and conservation objectives.

It is possible that natural disturbances combined with managed interventions, including some fisheries, could maintain site integrity and functionality in some designated areas. With much uncertainty concerning the impacts on biodiversity features resulting from new aquaculture developments, an 'adaptive management' approach has been applied using trials and essentially 'learning by doing' (Woolmer 2009; Online Resource Appendix B). In terms of specific measures, consideration should be given to establishing regional management plans governing the size of aquaculture operations and number of regional licences. This needs to take account of physical and hydrographic characteristics of water bodies present in the region (Kochmann et al. 2013). In certain circumstances it might be appropriate that a strategy for risk mitigation, such as contributions to the removal of any wild settlement that occurs, could be negotiated as part of the biosecurity aspect of the licensing process. Although there are uncertainties concerning the stability of their sterile condition and effectiveness, in areas where wild settlement is currently absent or where stocks are very low, the use of triploid Pacific oysters within aquaculture should be considered. The spatial extent of any removal of wild settlement would need to be agreed between growers and agencies but a focus on particularly sensitive habitats, such as $S a$ bellaria reefs, might be prioritized. In addition, efforts to increase populations of vulnerable or scarce species, such as the restoration of native oyster (Ostrea edulis) in the Blackwater estuary (Herbert et al. 2012), could also be encouraged. The economic feasibility of different management options needs to the assessed and capacity building is required in many of these areas to deliver these approaches.

Acknowledgments Much of the research was conducted for the Shellfish Association of Great Britain (SAGB) with funding from the European Commission and British Government (Defra). We are particularly grateful to SAGB, Defra, The Marine Management Organisation and Seafish among others for their contributions on the project steering committee. We are also grateful to may acknowledged experts on Pacific oysters including Karsten Reise, Alfred Wagner Institute for Polar and Marine Research, Germany; Jennifer Ruseink, University of Washington, Seattle, USA; John King, University of Wales (Bangor); Nicolas Desroy IFREMER, France; Ximing Guo, Rutgers University, USA; Ian Laing, Mike Gubbins and Rachel Hartnell, Centre for Environment, Fisheries and Aquaculture Science, UK; Martin Syvret, Aquafish Solutions Ltd, UK; John Bayes, Seasalter Shellfish (Whitstable) Ltd, UK; Gary Wordsworth, Othniel Oysters, UK; Richard Haward and Mersea oystermen. We are also grateful to the reviewers of this manuscript for their helpful and constructive comments. Errors remain the exclusive responsibility of the authors.

Role of funding source The review is based on a report commissioned by the Shellfish Association of Great Britain.

Open Access This article is distributed under the terms of the Creative Commons Attribution 4.0 International License (http://creativecommons.org/licenses/by/4.0/), which permits unrestricted use, distribution, and reproduction in any medium, provided you give appropriate credit to the original author(s) and the source, provide a link to the Creative Commons license, and indicate if changes were made. 


\section{References}

Allen SK Jr, Guo X (1996) Triploids for biological containment. The risk of heteroploid mosaics. In: Levin MA, Angle JS, McIntyre T, Yu H (eds) Proceedings of the third international conference on risk assessment methodologies. http://www.nbiap.vt.edu/brarg/brasym96/allen96.htm

Allen SK, Howe A, Gallivan T, Guo X, DeBrosse G (1999) Genotype and environmental variations in reversion of triploid Crassostrea gigas to the heteroploid mosaic state. J Shellfish Res 18:293

Arakawa KY (1990) Natural spat collecting in the Pacific oyster Crassostrea gigas (Thunberg). Mar Behav Physiol 17:95-128

Bax N, Carlton JT, Mathews-Amos A, Haedrich RL, Howarth FG, Purcell JE, Rieser A, Gray A (2001) The control of biological invasions in the world's oceans. Conserv Biol 15:1234-1246

BBC (2015) Reconsider the oyster! Food programme BBC radio 4. http://www.bbc.co.uk/programmes/ b054pbb5

Borsje BW, van Wesenbeeck BK, Dekker F, Paalvas P, Bouma TJ, van Katwijk MM, de Vries MB (2011) How ecological engineering can serve in coastal protection. Ecol Eng 37:113-122

Brandt G, Wehrmann A, Wirtz KW (2008) Rapid invasion of Crassostrea gigas into the German Wadden Sea dominated by larval supply. J Sea Res 59:279-296

Buettger H, Nehls G, Witte S (2011) High mortality of Pacific oysters in a cold winter in the North-Frisian Wadden Sea. Helgol Mar Res 65:525-532

Byers J (2009) Competition in marine invasions. In: Rilov G, Crooks J (eds) Biological invasions in marine ecosystems. Springer, Berlin

Cadée GC (2008a) Oystercatchers Haematopus ostralegus catching Pacific oysters Crassostrea gigas. Basteria 72:25-31

Cadée GC (2008b) Herring gulls feeding again on Pacific oysters Crassostrea gigas in the Dutch Wadden Sea near Texel. Basteria 72:33-36

Cardoso JFM, Langlet D, Loff JF, Martins AR, Witte JIJ, Santos PT, Van de Veer Henk W (2007) Spatial variability in growth and reproduction of the Pacific oyster Crassostrea gigas (Thunberg 1793) along the west European coast. J Sea Res 57:303-315

Cassis D, Pearce CM, Maldonado MD (2011) Effects of the environment and culture depth on growth and mortality in juvenile Pacific oysters in the Strait of Georgia, British Columbia. Aquac Environ Interact $1: 259-274$

Chavez-Villalba J, Cochard JC, Le Pennec M, Nbarret J, Enriquez-Ciaz M, Caceres-Martinez C (2003) Effect of temperature and feeding regimes on gametogenesis and larval production in the oyster Crassostrea gigas. J Shellfish Res 22:721-731

Cognie B, Haure J, Barille L (2006) Spatial distribution in a temperate coastal ecosystem of the wild stock of the farmed oyster Crassostrea gigas (Thunberg). Aquaculture 259:249-259

Copp GH, Goddard MJ, Russell IC, Peeler EJ, Gherardi F, Tricarico E, Miossec L, Goulletquer P, Almeida D, Britton JR, Vilizzi Mumford J, Williams C, Reading A, Rees EMA, Merino-Aguirre R (2016a) A preliminary evaluation of the European Non-Native Species In Aquaculture Risk Assessment Scheme applied to species listed on Annex IV of the EU Alien Species Regulation. Fish Manag Ecol 23:12-20

Copp GH, Russell IC, Peeler EJ, Gherardi F, Tricarico E, MacLeod A, Cowx IC, Nunn Ad, Occhipinti Ambrogi A, Savini D, Mumford J, Britton JR (2016b) The European Non-native Species in Aquaculture Risk Analysis Scheme (ENSARS) — a summary of assessment protocols and decision making tools for use in alien species in aquaculture and stock enhancement. Fish Manag Ecol 23:1-11

Cotter E, Malham SK, O'Keeffe S, Lynch SA, Latchford JW, King JW, Beaumont AR, Culloty SC (2010) Summer mortality of the Pacific oyster, Crassostrea gigas, in the Irish Sea: the influence of growth, biochemistry and gametogenesis. Aquaculture 303:8-21

Crooks JA (2009) The role of exotic marine ecosystem engineers. In: Rilov G, Crooks JA (eds) Biological invasions of marine ecosystems. Springer, Berlin

DAISIE (2016) Delivering alien species inventories for Europe. Crassotrea gigas species factsheet. http:// www.europe-aliens.org/speciesFactsheet.do?speciesId=50156\#. Accessed Jan 2016

Dauvin JC, Tous Rius A, Ruellet T (2009) Recent expansion of two invasive crabs species Hemigrapsus sanguineus (de Haan 1835) and H. takanoi Asakura and Watanabe, 2005 along the Opal Coast, France. Aquat Invasions 4:451-465. doi:10.3391/ai.2009.4.3.3

Deslous-Paoli JM, Souchu P, Mazouni N, Juge C, Dagault F (1998) Relationship between environment and resources: impact of shellfish farming on a Mediterranean lagoon (Thau, France). Oceanol Acta 21:831-843 
Desroy N, Dubois SB, Fournie J, Ricquiers L, Le Mao P, Guerin L, Gerla D, Rougerie M, Legendre A (2011) The conservation status of Sabellaria alveolata (L.) (Polychaeta: Sabellaridae) reefs in the Bay of Mont Saint Michel. Aquat Conserv 21:462-471

Diederich S, Nehls G, van Beusekom JEE, Reise K (2005) Introduced Pacific oysters (Crassostrea gigas) in the northern Wadden Sea: invasion accelerated by warm summers? Helgol Mar Res 59:97-106

Dolmer P, Holm MW, Strand A, Lindegarth S, Bodvin T, Norling P, Mortensen S (eds) (2014) The invasive Pacific oyster in Scandinavian coastal waters: a risk assessment on the impact in different habitats and climate conditions. Fisken og havet Report No. 2/2014. Norwegian Institute of Marine Research, Bergen

Drinkwaard AC (1999) Introductions and developments of oysters in the North Sea area: a review. Helgol Meeresun 52:301-308

Dubois SB, Committo JA, Oliver F, Reti're C (2006) Effects of epibionts on Sabellaria alveolata (L.) biogenic reefs and their associated fauna in the Bay of Mont Saint-Michel. Estuar Coast Shelf Sci 68:635-646

Dumbauld BR, Ruesink JL, Rumrill SS (2009) The ecological role of bivalve shellfish aquaculture in the estuarine environment: a review with application to oyster and clam culture in West coast (USA) estuaries. Aquaculture 290:196-223

Dutertre M, Beninger PG, Barille L, Papin M, Haure J (2010) Rising water temperatures, reproduction and recruitment of an invasive oyster, Crassostrea gigas, on the French Atlantic coast. Mar Environ Res 69:1-9

Elton CS (1958) The ecology of invasions of animals and plants. Methuen, London, UK

English Nature (1999) Habitat regulations guidance note 3. The determination of likely significant effect under the conservation (Natural Habitats \&c) Regulations 1994. Peterborough

Eno C (1994) Monitoring the temperature regimes of which the Pacific oyster Crassostrea gigas is subject to in coastal inlets in Britain (The Fleet lagoon and Teign and Dart estuaries) in relation to their reproductive success. Report to Joint Nature Conservation Committee

Escapa M, Isacch JP, Daleo P, Alberti J, Iribarne O, Borges M, Dos Santos EP, Gagliardini DA, Lasta M (2004) The distribution and ecological effects of the introduced Pacific oyster Crassostrea gigas (Thunberg 1793) in northern Patagonia. J Shellfish Res 23:765-772

Eschweiler N, Christensen HT (2011) Trade-off between increased survival and reduced growth for Blue mussels living on Pacific oyster reefs. J Exp Mar Biol and Ecol 403:90-95

European Commission (2000) MANAGING NATURA 2000 SITES: The provisions of Article 6 of the 'Habitats' Directive 92/43/EEC. Brussels

European Commission (2001) Assessment of plans and projects significantly affecting Natura 2000 sites Methodological guidance on the provisions of Article 6(3) and (4) of the Habitats Directive 92/43/ EEC. http://www.ec.europa.eu/environment/nature/natura2000/management/guidance_en.htm. Accessed Jul 2016

European Commission (2016a) European commission at work: infringement procedure. http://www.ec. europa.eu/atwork/applying-eu-law/infringements-proceedings/index_en.htm. Accessed Jan 2016

European Commission (2016b) Member countries of the European Union. http://www.europa.eu/about-eu/ countries/index_en.htm. Accessed Jul 2016

European Union (2014) REGULATION (EU) No 1143/2014 OF THE EUROPEAN PARLIAMENT AND OF THE COUNCIL on the prevention and management of the introduction and spread of invasive alien species. Brussels

FAO (2016a) Food and Agriculture Organisation of the United Nations. Species Fact Sheets: Crassostrea gigas (Thunberg, 1793). http://www.fao.org/fishery/species/3514/en. Accessed Feb 2016

FAO (2016b) FAO yearbook. Fishery and aquaculture statistics. 2014/FAO. Rome, Italy. http://www.fao. org/3/a-i5555e.pdf. Accessed Jul 2016

Fey F, Dankers N, Steenbergen J, Goudswaard K (2010) Development and distribution of the nonindigenous Pacific oyster (Crassostrea gigas) in the Dutch Wadden Sea. Aquacul Int 18:45-59

Gofas S (2013). Crassostrea angulata (Lamarck 1819). In: MolluscaBase (2016). http://www.molluscabase. org/aphia.php?p=taxdetails\&id=146900. Accessed 22 Jul 2016

Gong N, Yang H, Zhang G, Landau BJ, Guo X (2004) Chromosome inheritance in triploid Pacific oyster Crassostrea gigas Thunberg. Heredity 93:408-415

Goss-Custard JD, Triplet P, Suer F, West A (2006) Critical thresholds of disturbance by people and raptors. Biol Conserv 127:88-97

Gottlieb SJ, Schweighofer ME (1996) Oysters and the Chesapeake Bay ecosystem: a case for exotic species introduction to improve environmental quality? Estuaries 19:639-650 
Goulletquer P (2009) History and economic consequences of species invasions on Atlantic coast: "good" \& "bad" examples. Total foundation—port cros symposium 2009. http://www.archimer.ifremer.fr/doc/ 00000/6828/

Goulletquer P, Heral M (1997) Marine molluscan production trends in France: from fisheries to aquaculture. In: MacKenzie CL, Burrel VG, Rosenfield A, Hobart WL (eds). The history, present condition and future of the molluscan fisheries of north and central America, and Europe. NOAA Technical Report 129, vol 3, pp. 137-164

Goulletquer P, Lombas I, Prou J (1987) Growth and reproduction of the manila clam Ruditapes philippinarum and the Pacific oyster Crassostrea gigas as influenced by the immersion time. IFREMER Report

Goulletquer P, Soletchnik P, Le Moine O, Razet D, Geairon P, Faury N (1998) Summer mortality of the Pacific cupped oyster Crassostrea gigas in the Bay of Marennes-Oleron (France). In: Proceedings of Council Meeting of the International Council for the Exploration of the Sea, Cascais (Portugal), 16-19 Sep 1998. Mariculture Committee CM 1998/CC: 14 Theme Session (CC): Population Biology

Grangeré K, Lefebvre S, Bacher C, Cugier P, Ménesguen A (2010) Modelling the spatial heterogeneity of ecological processes in an intertidal estuarine bay: dynamic interactions between bivalves and phytoplankton. Mar Ecol Prog Ser 415:141-158

Green DS, Crowe TP (2013) Physical and biological effects of introduced oysters on biodiversity in an intertidal boulder field. Mar Ecol Prog Ser 482:119-132

Green DS, Crowe TP (2014) Context-and density-dependent effects of introduced oysters on biodiversity. Biol Invasions 15:1145-1163

Green DS, Boots B, Crowe TP (2012) Effects of non-indigenous oysters on microbial diversity and ecosystem functioning. PLoS One 7(10):e48410. doi:10.1371/journal.pone.004810

Guo X, Allen SK (1994) Reproductive potential and genetics of triploid Pacific oysters, Crassostrea gigas (Thunberg). Biol Bull 187:309-318

Guo X, Wang Y, Xu Z, Yang H (2009) Chromosome set manipulation in shellfish. In: Burnell G, Allan G (eds) New technologies in aquaculture: improving production efficiency, quality and environmental management. Woodhead Publishing, Cambridge, pp 165-194

Gutiérrez JL, Jones CG, Strayer DL, Iribarne OO (2003) Molluscs as ecosystem engineers: the role of shell production in aquatic habitats. Oikos 101:79-90

Guy C, Roberts D (2010) Can the spread of non-native oysters (Crassostrea gigas) at the early stages of population expansion be managed? Mar Pollut Bull 60:1059-1064

Hall SJ, Harding MJC (1997) Physical disturbance and marine benthic communities: the effects of mechanical harvesting of cockles on non-target benthic infauna. J Appl Ecol 34:497-517

Hawkins SJ (2012) Marine Conservation in a rapidly changing world. Aquat Conserv Mar Freshw Ecosyst 22:281-287

Herbert RJH, Roberts C, Humphreys J, Fletcher S (2012) The Pacific oyster (Crassostrea gigas) in the UK: economic, legal and environmental issues associated with its cultivation, wild establishment and exploitation. Report for the Shellfish Association of Great Britain

Hily C (1991) Is the activity of benthic suspension feeders a factor controlling water quality in the Bay of Brest? Mar Ecol Prog Ser 69:179-188

Hollander J, Blomfeldt J, Carlsson P, Strand Å (2015) Effects of the alien Pacific oyster (Crassostrea gigas) on subtidal macrozoobenthos communities. Mar Biol 162:547-555

Hoskin R, Tyldesley D (2006) How the scale of effects on internationally designated nature conservation sites in Britain has been considered in decision making: a review of authoritative decisions. Engl Nat Res Rep, No 704

Humphreys J (2010) The introduction of the Manila clam to British coastal waters. Biologist 57:134-138

Humphreys J, Herbert RJH, Roberts C, Fletcher S (2014) A reappraisal of the history and economics of the Pacific oyster in Britain. Aquaculture 428-429:117-124

ICES (2005) International council for the exploration of the seas (ICES) code of practice on the introductions and transfers of marine organisms. International Council for the Exploration of the Seas, Copenhagen

IPCC (2014) Climate change 2014: impacts, adaptation, and vulnerability. Part A: global and sectoral aspects. In: Field CB, Barros VR, Dokken DJ, Mach KJ, Mastrandrea MD, Bilir TE, Chatterjee M, Ebi KL, Estrada YO, Genova RC, Girma B, Kissel ES, Levy AN, MacCracken S, Mastrandrea PR, White LL (eds) Contribution of Working Group II to the fifth assessment report of the intergovernmental panel on climate change. Cambridge University Press, Cambridge

IUCN (2000) IUCN Guidelines for the prevention of biodiversity loss caused by alien invasive species. Approved by the 51st meeting of the IUCN council, Gland, Switzerland, February 2000. http://www. iucn.org/themes/ssc/publications/policy/invasivesEng.htm 
Jones CG, Gutierrez JL (2007) On the purpose, meaning and usage of the physical ecosystem engineering concept. In: Cuddington K, Byers JE, Wilson WG, Hastings A (eds) Ecosystem engineers. Plants to protists. Elsevier, San Diego, pp 3-24

Jones CG, Lawton JH, Shachak M (1994) Organisms as ecosystem engineers. Oikos 689:373-386

Jones CG, Lawton JH, Shachak M (1997) Positive and negative effects of organisms as physical ecosystem engineers. Ecology 78:1946-1957

Jouaux A, Heude-Berthelin C, Sourdaine P, Mathieu M, Kellner K (2010) Gametogenic stages in triploid oysters Crassostrea gigas: irregular locking of gonial proliferation and subsequent reproductive effort. J Exp Mar Biol Ecol 395:162-170

Kaiser MJ, Broad G, Hall SJ (2001) Disturbance of intertidal soft-sediment benthic communities by cockle hand raking. J Sea Res 45:119-130

Kater B, Baars D, Perdon J, van Riet M (2002) Het inventariseren van sublitorale oesterbestanden in de Oosterschelde mbv side scan sonar. RIVO rapp C058/02 pp26

Kelly JR, Volpe JP (2007) Native eelgrass (Zostera marina L.) survival and growth adjacent to non-native oysters (Crassostrea gigas Thunberg) in the Starit of Georgia, British Columbia. Bot Mar 50:143-150

Kelly JR, Proctor E, Volpe JP (2008) Intertidal community structure differs significantly between substrates dominated by native eelgrass (Zostera marina L.) and adjacent to the introduced oyster Crassostrea gigas. Hydrobiologia 596:57-66

King JW, Malham SK, Skov MW, Cotter E, Latchford JW, Culloty SC, Beaumont AR (2006) Growth of Crassostrea gigas spat and juveniles under differing environmental conditions at two sites in Wales. Aquat Living Resour 19:289-297

Kochman J, Carlsson J, Crowe TP, Mariani S (2012) Genetic evidence for the uncoupling of local aquaculture activities and a population of an invasive species-a case study of Pacific oysters (Crassostrea gigas). J Hered 103:661-671

Kochmann J, Buschbaum C, Volenborn N, Reise K (2008) Shift from native mussels to alien oysters: differential effects of ecosystem engineers. J Exp Mar Biol Ecol 364:1

Kochmann J, O’Beirn F, Yearsley J, Crowe TP (2013) Environmental factors associated with invasion: modelling occurrence data from a coordinated sampling programme for Pacific oysters. Biol Invasions $15: 2265-2279$

Lejart M, Hily C (2005) Proliferation of Crassostrea gigas (Thunberg) in the Bay of Brest: first estimations of the stock and its impact on the global functioning of the ecosystem. 8th international conference on shellfish restoration. Brest

Lejart M, Hily C (2011) Differential response of benthic macrofauna to the formation of novel oyster reefs (Crassostrea gigas, Thunberg) on soft and rocky substrate in the intertidal Bay of Brest, France. J Sea Res 65:84-93

Marchais V, Schaal G, Grall J, Lorrain A, Nerot C, Richard P, Chauvaud L (2013) Spatial variability of stable isotope ratios in oysters (Crassostrea gigas) and primary producers along an estuarine gradient (Bay of Brest, France). Estuar Coast 36:808-819

Markert A, Wehrmann A, Kronke I (2010) Recently established Crassostrea reefs versus native Mytilus beds: differences in ecosystem engineering affects the macrofaunal communities (Wadden Sea of Lower Saxony, southern German Bight). Biol Invasions 12:15-32

Markert AW, Esser W, Frank D, Wehrmann A, Exo K-M (2013) Habitat change by the formation of alien Crassostrea-reefs in the Wadden Sea and its role as feeding sites for waterbirds. Estuar Coast Shelf S 131:41-51

McKinney ML, Lockwood JL (1999) Biotic homogenization: a few winners replacing many losers in the next mass extinction. Trends Ecol Evol 14:450-453

McKnight W (2011) Pacific Oyster distribution within the North East Kent European Marine Sites (intertidal) Phase 4 Report for Natural England. Peterborough

McKnight W (2012) Pacific oyster distribution within the North East Kent European Marine Sites (intertidal). Phase 5 Report for Natural England. Peterborough

McKnight W, Chudleigh IJ (2015) Pacific oyster Crassostrea gigas control within the inter-tidal zone of the North East Kent Marine Protected Areas, UK. Conserv Evid 12:28-32

Miossec L, Le Deuff RM, Goulletquer P (2009) Alien species alert: Crassostrea gigas (Pacific oyster). Copenhagen, International Council for the Exploration of the Sea. ICES Co-operative Research Report No. 299

Morrissey T, McClearly S, Collins E, Henshilwood K, Cheslett D (2015) An investigation of ostreid herpes virus microvariants found in Crassostrea gigas oyster producing bays in Ireland. Aquaculture 442:86-92

MSFD (2008) EU Marine Strategy Framework Directive. Directive 2008/56/EC on establishing a framework for community action in the field of marine environmental policy 
Nehls G, Buttger H (2007) Spread of the Pacific oyster Crassostrea gigas in the Wadden Sea: causes and consequences of a successful invasion. A report for The Common Wadden Sea Secretariat, Wilhelmshaven, p 55

Nehls G, Diederich S, Thieltges DW, Strasser M (2006) Wadden Sea mussel beds invaded by oysters and slipper limpets: competition or climate control? Helgol Mar Res 60:135-143

Nehls G, WitteS, Büttger H, Dankers N, Jansen J, Millat G, Herlyn M, MarkertA, Kristensen PS, Ruth M, Buschbaum C, Wehrmann A (2009) Beds of blue mussels and Pacific oysters. Thematic Report No. 11. In: Marencic H, De Vlas J. (eds). Quality status report 2009. Wadden Sea Ecosystem No. 25. Trilateral Monitoring and Assessment Group, Common Wadden Sea Secretariat, Wilhelmshaven, p 29

Nehring S, Reise K, Dankers N, Kristensen PS (2009) Quality status report 2009 Thematic Report No.7. Wadden Sea Ecosystem Report 25

Nell JA (2002) Farming triploid oysters. Aquaculture 210(1-4):69-88

Normand J, Le Pennec M, Boudry P (2008) Comparative histological study of gametogenesis in diploid and triploid Pacific oysters (Crassostrea gigas) reared in an estuarine farming site in France during the 2003 heatwave. Aquaculture 282:124-129

Normand J, Ernande B, Haure J, McCombie H, Boudry P (2009) Reproductive effort and growth in Crassostrea gigas: comparison of young diploid and triploid oysters issued from natural crosses or chemical induction. Aquat Biol 7:229-241

North EW, Schlag Z, Hood RR, Li M, Zhong L, Gross T, Kennedy VS (2008) Vertical swimming behaviour influences the dispersal of simulated oyster larvae in a coupled particle-tracking and hydrodynamic model of Chesapeake Bay. Mar Ecol Prog Ser 359:99-115

NSWDPI (2015) New South Wales Department of Primary Industries. Fishing and Aquaculture. Pacific oyster (Crassostrea gigas) http://www.dpi.nsw.gov.au/fisheries/pests-diseases/marine-pests/nsw/ pacific-oyster. Accessed 25 Mar 2015

O'Connor WA, Dove MC (2009) The changing face of oyster culture in New South Wales, Australia. J Shellfish Res 28:803-811

Olden JD (2006) Biotic homogenization: a new research agenda for conservation biogeography. J Biogeog 33:2027-2039

Olyarnik SV, Bracken MES, Byrnes JE, Hughes AR, Hultgren KM, Stachowicz JJ (2009) Ecological factors affecting community invisibility. In: Rilov G, Crooks JA (eds) Biological invasions in marine ecosystems. Springer, Berlin, pp 215-238

Padilla DK (2010) Context-dependent impacts of a non-native ecosystem engineer, the Pacific oyster Crassostrea gigas. Integr Comp Biol 50:213-225

Piazza BP, Banks PD, La Peyre MK (2005) The potential for created oyster shell reefs as a sustainable shoreline protection strategy in Louisiana. Restor Ecol 13:499-506

Piersma T, Koolhaas A, Dekinga A, Beukema JJ, Dekker R, Essink K (2001) Long-term indirect effects of mechanical cockle-dredging on intertidal bivalve stocks in the Wadden Sea. J Appl Ecol 38:976-990

Reise K (1998) Pacific oyster invade mussel beds in the European Wadden Sea. Senkenbergiana Marit 28:167-175

Reise K, Dankers N, Essink K (2005) Introduced Species. In: Essink K, Dettmann C, Farke H, Laursen K, Luersen G, Marencic H, Wiersinga W (eds) Wadden Sea quality status Report 2004. Wadden Sea Ecosystem vol 19, pp 155-161

Rico-Villa B, Le Coza JR, Minganta C, Robert R (2006) Influence of phytoplankton diet mixtures on microalgae consumption, larval development and settlement of the Pacific oyster Crassostrea gigas (Thunberg). Aquaculture 256:377-388

Rilov G (2009) The integration of invasive species into marine ecosystems. In: Rilov G, Crooks JA (eds) Biological invasions in marine ecosystems. Springer, Berlin, pp 241-244

Rilov G, Crooks JA (eds) (2009) Biological invasions in marine ecosystems. Springer, Berlin

Robbins TE (2005) Evaluation of Pacific oyster cultivation methods in the South West of England. MSc Thesis, University of Plymouth, Plymouth

Ronholm J, Lau F, Banerjee SK (2016) Emerging seafood preservation techniques to extend freshness and minimize Vibrio contamination. Front Microbiol. doi:10.3389/fmicb.2016.00350

Rowley AF, Cross ME, Culloty SC, Lynch SA, Mackenzie CL, Morgan E, O'Riordan RM, Robins PE, Smith AL, Thrupp TJ, Vogan CL, Wootton EC, Malham SK (2014) The potential impact of climate change on the infectious diseases of commercially important shellfish populations in the Irish Sea-a review. ICES J Mar Sci 71:741-759

Ruesink JL (2007) Biotic resistance and facilitation of a non-native oyster on rocky shores. Mar Ecol Prog Ser 331:1-9 
Ruesink JL, Lenihan HS, Trimble AC, Heiman KW, Micheli F, Byers JE, Kay MC (2005) Introduction of non-native oysters: ecosystem effects and restoration implications. Annu Rev Ecol Evol Syst 36:643-689

Scheiffarth G, Ens B, Schmidt A (2007) What will happen to birds when Pacific Oysters take over the mussel beds in the Wadden Sea? Wadden Sea Newsl 1:10-14

Schrobback P, Coglan L, Pascoe S (2014) Socio-economic determinants for industry development: the case of Australia's Sydney rock oyster industry. Aquat Living Resour 27:167-175

Scyphers SB, Powers SP, Heck KL Jr, Byron D (2011) Oyster reefs as natural breakwaters mitigate shoreline loss and facilitate fisheries. PLoS One 6(8):e22396. doi:10.1371/journal.pone.0022396

Segarra A, Pépin JF, Arzul I, Morga B, Faury N, Renault T (2010) Detection and description of a particular Ostreid herpesvirus 1 genotype associated with massive mortality outbreaks of Pacific oysters, Crassostrea gigas, in France in 2008. Virus Res 153:92-99

Sewell J, Lindsley-Leake S, Tyler-Walters H (2010) Non-native species risk assessment for the Pacific oyster Crassostrea gigas. Report to Great Britain non-native species secretariat and Defra

Smaal AC, van Stralen MR, Craeymeersch J (2005) Does the introduction of the Pacific oyster Crassostrea gigas lead to species shifts in the Wadden Sea? In: Dame RF, Olenin S (eds) The comparative roles of suspension feeders in ecosystems. Springer, Berlin, pp 277-289

Smaal AC, Wijsman JWM, Poelman M (2006) Proliferation of the Pacific oyster Crassostrea gigas in Dutch coastal waters and its consequences for human use. ICES Annual Science Conference 2006, theme session G: Human health risks and marine environmental quality, Maastricht

Smaal AC, Kater B, Wijsman J (2009) Introduction, establishment and expansion of the Pacific oyster Crassostrea gigas in the Oosterschelde (SW Netherlands). Helgol Mar Res 63:75-83

Smith IP, Guy C, Donnan D (2015) Pacific oysters, Crassostrea gigas, established in Scotland. Aquat Conserv Mar Freshw Ecosyst 25:733-742

Sousa R, Gutiérrez JL, Aldridge DC (2009) Non-indigenous invasive bivalves as ecosystem engineers. Biol Invasions 11:2367-2385

Spalding MD, Fox HE, Allen GR, Davidson N, Ferdana ZA, Finlayson M, Halpern BS, Jorge MA, Lombana A, Lourie SA, Martin KD, McManus E, Molnar J, Recchia CA, Robertson J (2007) Marine ecoregions of the World: a bioregionalization of coastal and shelf areas. Bioscience 57:573-583

Spencer BE, Key D, Millican PF, Thomas MJ (1978) The effect of intertidal exposure on the growth and survival of hatchery-reared Pacific oysters (Crassostrea gigas Thunberg) kept in trays during their first on-growing season. Aquaculture 13:191-203

Spencer BE, Edwards DB, Kaiser MJ, Richardson CA (1994) Spatfalls of the non-native Pacific oyster, Crassostrea gigas, in British waters. Aquat Conserv Mar Freshw Ecosyst 4:203-217

Spencer B, Kaiser MJ, Edwards DB (1998) Intertidal clam harvesting: benthic community change and recovery. Aquac Res 29:429-437

Suquet M, Malo F, Quere C, Ledu C, Le Grand J, Benabdelmouna A (2016) Gamete quality in triploid Pacific oyster (Crassostrea gigas). Aquaculture 451:11-15

Syvret M, Fitzgerald A, Hoare P (2008) Development of a Pacific oyster aquaculture protocol for the UKTechnical Report FIFG project no: 07/Eng/46/04. Report for the Sea Fish Industry Authority

Tallis HM, Ruesink JL, Dumbauld BR (2009) Oysters and aquaculture practices affect eelgrass density and productivity in a Pacific Northwest estuary. J Shellfish Res 28:251-261

Tamburri MN, Zimmer CA (2007) Mechanisms reconciling gregarious larval settlement with adult cannibalism. Ecol. Monog 77:255-268

Thresher RE, Kuris AM (2004) Options for managing invasive species. Biol Invasions 6:295-300

Troost K (2010) Causes and effects of a highly successful marine invasion: case-study of the introduced Pacific oyster Crassostrea gigas in continental NW European estuaries. J Sea Res 64:145-165

Troost K, Gelderman E, Kamermans P, Smaal AC, Wolff WJ (2009) Effects of an increasing filter feeder stock on larval abundance in the Oosterschelde estuary (SW Netherlands). J Sea Res 61:153-164

van den Brink AM, Wijnhoven S, McLay CL (2012) Competition and niche segregation following the arrival of Hemigrapsus takanoi in the formerly Carcinus maenas dominated Dutch delta. J Sea Res 73:126-136. doi:10.1016/j.seares.2012.07.006

van der Zee EM, van der Heide T, Donadi S, Eklöf JS, Eriksson BK, Olff H, van der Veer HW, Piersma T (2012) Spatially extended habitat modification by intertidal reef-building bivalves has implications for consumer-resource interactions. Ecosystems 15:664-673

Wagner EL, Ruesink JL, Dumbauld BR, Hacker SD, Wisehart LM (2012) Density dependent effects of an introduced oyster, Crassostrea gigas, on native intertidal eelgrass, Zostera marina. Mar Ecol Prog Ser 468:149-160 
Walles B, Mann R, Ysebaert T, Troost K, Herman PMJ, Small AC (2015) Demography of the ecosystem engineer Crassostrea gigas, related to vertical reef accretion and reef persistence. Estuar Coast Shelf Sci 154:224-233

Wehrmann A, Markert A, May P, Schieck P, Schmidt A (2006) Gefährdungspotential der eulitoralen Miesmuschelbänke im Niedersächsischen Wattenmeer durch die Bioinvasion der Pazifischen Auster Crassostrea gigas. Abschlussbericht Projekt 7/02 der Niedersächsischen Wattenmeer- Stiftung, 110 pp

Wheat E, Ruesink JL (2013) Commercially-cultured oysters (Crassostrea gigas) exert top-down control on intertidal pelagic resources in Willapa Bay, Washington, USA. J Sea Res 81:33-39

Wijsman JWM, Dubbeldam M, De Kluijver MJ, Van Zanten E, Van Stralen MR, Smaal AC (2008). Wegvisproef Japanse oesters in de Oosterschelde. Eindrapportage. Wageningen Imares, Institute for Marine Resources and Ecosystem Studies. Report CD63/08. CD63/08. Yerseke

Wilkie EM, Bishop MJ, O'Connor WA (2013) The density and spatial arrangement of the invasive oyster Crassostrea gigas determines its impact on settlement of native oyster larvae. Ecol Evol 3:4851-4860

Williamson M (1996) Biological Invasions. Chapman and Hall, London

Wood CA, Bishop JDD, Delduca EL, Davies C, Herbert RJH, Clark PF (2015) Hemigrapsus takanoi Asakura and Watanabe, 2005 (Crustacea: Decapoda: Brachyura: Grapsoidea): first records of the brush-clawed shore crab from Great Britain. Bioinvasions Rec 4:109-113

Woolmer A (2009). Appropriate assessment and shellfisheries: adaptive management protocol. Report to shellfish industry development strategy. Salacia-Marine Ltd

Wrange AL, Valero J, Harkestad LS, Strand $\varnothing$, Lindegarth Christensen HT, Dolmer P, Kristensen PS, Mortensen S (2010) Massive settlements of the Pacific oyster, Crassostrea gigas, in Scandinavia. Biol Invasions 12:1453-1458

zu Ermgassen PSE, Spalding MD, Blake B, Coen LD, Dumbauld B, Geiger S, Grabowski JH, Grizzle R, Luckenbach MW, McGraw K, Rodney W, Ruesink J, Powers SP, Brumbaugh RD (2012) Historical ecology with real numbers: past and present extent and biomass of an imperiled estuarine habitat. Proc R Soc B Biol Sci 279:3393-3400 